\title{
Strategic planning research through fifty years of Long Range Planning: a bibliometric overview
}

\section{Hugo Baier-Fuentes}

Universidad Católica de la Santísima Concepción, Concepción, Chile

\section{José M. Merigó}

University of Technology Sydney, Faculty of Engineering and Information Technology, School of Information, Systems, \& Modelling, Ultimo, Australia

University of Chile, School of Economics and Business, Department of Management Control and Information Systems, Santiago, Chile Luis Miranda

University of Chile, School of Economics and Business, Department of Management Control and Information Systems, Santiago, Chile Francisco J. Martínez-López

University of Granada, Department of Business Administration, Granada, Spain

\begin{abstract}
Long Range Planning (LRP) is the first journal focused on strategic planning. It was created in 1968 by the Long Range Planning Society, and it celebrated its $50^{\text {th }}$ anniversary in 2018 . This event led to the presentation of a complete bibliometric study aimed at identifying the most significant results that occurred in the journal during this period. For this purpose, bibliometric data were collected from the Web of Science Core Collection database, and two bibliometric approaches were used to analyze the journal's publications: a performance analysis and a graphical mapping of the literature. The first of these uses a wide range of productivity and influence indicators that include the number of publications and citations, the h-index, and citations by paper, among others. The second approach uses the VOSviewer software to deliver a graphical view of the various intellectual connections within LRP. The results of both bibliometric approaches are consistent and confirm LRP as a leading journal in strategic planning and management, with increasing participation of authors and universities from countries around the world.
\end{abstract}

Keywords

Bibliometrics; Web of Science; citations; h-index; VOS viewer

\section{Introduction}

Long Range Planning (LRP hereafter), established in 1968 , is a pioneering journal in the field of strategic management. According to Stiles (2000), the name of the journal was chosen to coincide with the Long Range Planning Society, which emerged in Paris during 1964 as the vision of 12 British researchers concerned about an emerging issue at the time: long-term planning. LRP was successfully led during its first 32 years by Cofounder and Editor in Chief Bernard Taylor. Its subsequent editors, namely, Charles Baden-Fuller,
James Robins, and Tomi Laamanen, maintained the mission of its founders. This mission is to help improve the understanding of strategic planning systems and continue to develop the various strategic practices used by the actors who contribute to the strategy of their countries, regions or organizations (Laamanen, 2017). During its 50 years in existence, LRP has covered different topics at the intersection of strategic management across diverse disciplines, publishing articles by the best academics and professionals (Stiles, 2000). This has enabled LRP to build a solid reputation and lead academic research in the 
field of strategic management. LRP currently has an impact factor of 3.221 and is among the top 50 Management journals in the Social Science Citation Index.

LRP celebrated its $50^{\text {th }}$ anniversary in 2017 , and in honor of that, this document analyzes and shows the main trends that occurred during the journal's five decades. By doing so, we can identify some of the leading trends in strategic planning research. To do this, we use several techniques and bibliometric tools to analyze all of the literature of the journal quantitatively and qualitatively. Bibliometrics involves two main methods, performance analysis and a mapping of science (Cobo et al., 2011a; Noyons et al., 1999). Performance analysis aims to assess the impact of scientific production citations made by different scientific actors including countries, universities or individuals. Science mapping seeks to show the structural and dynamic aspects of scientific research. This approach enriches performance analysis by highlighting issues that have received the most attention from a scientific community. Given their complementarity, both approaches are often developed in combination to validate and enrich the results obtained (Cobo et al., 2011b). Therefore, this study shows the results of combining both approaches with the ultimate aim of identifying the most significant aspects of the various scientific actors who have contributed to the development of LRP since 1968.

Currently, it is quite common for scientific journals to celebrate their most significant anniversaries with important issues or special publications, such as reviews, special issues, or editorial notes. The bibliometric study of a journal is important because through its combined methods - performance analysis and scientific mapping - it is possible to capture general and historical results and retrospectively evaluate the scientific trends and actors that have most impacted the journal. Thus, some of the journals that have published these analyses include Information Sciences in celebration of its $50^{\text {th }}$ anniversary (Merigó et al., 2018), European Journal of Marketing in recognition of its 50th anniversary (Martínez-López et al., 2018), International Journal of Intelligent Systems in its thirties (Merigó et al., 2017), Knowledge-Based Systems in its twenty-fifth year (Cobo et al., 2015), Journal of Product Innovation Management, and more recently, Journal of Knowledge Management in its twenty-first year (Gaviria-Marin et al., 2018). Finally, note that many other journals have already developed a bibliometric description to celebrate a special anniversary (Merigó et al., 2018).

This document is organized as follows. Section 2 describes the methodological aspects of the work. Specifically, aspects relevant to the main approaches involved in bibliometrics are described. Section 3 presents the results of the performance analysis and science mapping of all literature published in the 50 years of LRP. Finally, Section 4 provides a brief description of the main findings and conclusions of the analysis.

\section{Bibliometric methods}

Bibliometrics is a technique that explores literature quantitatively using bibliographic references obtained from different reference databases. In this document, the Web of Science (WoS hereafter), belonging to Clarivate Analytics, is used to compile LRP references. The WoS gathers several reference databases, among which the Science Citation Index Expanded (SCIE), the Social Sciences Citation Index (SSCI) and the Emerging Sources Citation Index (ESCI), are included. WoS currently covers more than 18,000 high-impact journals, making it the world's leading reference database (Baier-Fuentes et al., 2019; Gaviria-Marin et al., 2019). Note, however, that there are several other reference databases, such as Scopus, Scielo, and EconLit, among others.

There are many techniques and methodologies that have been used to develop bibliometric analyses. Some studies indicate that bibliometric methodologies include a quantitative analysis of the literature, also known as performance analysis (Noyons et al., 1999). In recent years, science mapping has also been considered an important technique within bibliometrics (Cobo et al., 2011b). The aim of both approaches is to analyze bibliographic material and provide an overview of a set of documents that are limited to a particular field of research, or even, as in our case, to a journal. In order to analyze all the literature published in the journal thoroughly, this study develops both bibliometric approaches, i.e., a performance analysis and a science mapping of all LRP bibliographic records.

Performance analysis uses a series of bibliometric indicators, with the number of publications and the number of citations being the most popular. However, several other indicators that have recently been used provide a more representative and informative view of the data. 
This has led to uncertainty as to which is the optimal indicator to best represent the information (Podsakoff et al., 2008). Therefore, in order to reduce that uncertainty, this study includes several indicators that are generally considered to be the most popular. Among them, we use the total number of documents, the paper citations and the $\mathrm{h}$-index. The latter integrates the number of publications and the number of citations into a single measure (Hirsch, 2005). The h-index is an indicator of influence, which indicates the number $\mathrm{h}$ of studies of a total $\mathrm{N}$, which have received at least $\mathrm{h}$ citations. Note that other indicators can be found in the literature, such as the g-index (Egghe, 2006) or the hg-index (Alonso et al., 2009). However, the methodology used in this study aims to measure the productivity and influence of all the scientific actors involved in LRP and to act in this sense as a valuable, informative resource to the readers of the journal. Other indicators used in performance analyses are citation thresholds that measure the number of documents that are above a specific number of citations and thus allow the journal's references to be ranked according to their level of influence. In addition, other more general indicators, such as university rankings and the number of documents per person, are shown, allowing a broader perspective of the research published in LRP.

Science mapping is an important bibliometric technique that is used to generate a representation of the intellectual connections of a dynamically changing scientific knowledge system (Small, 1999, 1997). In other words, it analyzes the structure of the relationships between all scientific actors interacting in a particular field of research (Cobo et al., 2011b). It is important to mention that the use of science mapping has been strengthened thanks to the development of software that allows the analysis of bibliographic information (Cobo et al., 2011b). Some of the most popular software used in the literature includes, for example, Bibexcel (Persson et al., 2009), CiteSpace II (Chen, 2006), IN-SPIRE (Wise, 1999), VantagePoint (Porter and Cunningham, 2005), and VOSviewer (van Eck and Waltman, 2010). In this study, we used VOSviewer software, which visualizes the results of analysis using indicators such as bibliographic coupling (Kessler, 1963), co-citation (Small, 1973), co-authorship (Glänzel, 2001; Peters and van Raan, 1991), and co-words (Callon et al., 1983). Bibliographic coupling occurs when two documents cite the same third article. Co-citation measures the most cited documents and occurs when two documents receive a citation from the same third paper. Co-authorship measures the degree of co-authors among the most productive sources. Co-word analysis uses the most important keywords in documents and is used to study the conceptual structure of a field of research. Another interesting function that can be performed with this technique is a temporal analysis of the research field, allowing the analysis and observation of the evolution of the cognitive structure of a field (Noyons et al., 1999).

Finally, it is important to clarify that the results obtained from performance analysis and science mapping give a current but retrospective overview of the last 50 years of LRP. Therefore, it is logical to think that these results will change over time, especially for more recent publications that have yet to significantly improve their indicators.

\section{Results}

\subsection{LRP Bibliometric performance analysis}

\subsubsection{Publication and citation structure of LRP}

LRP published its first issue in September 1968. In the following years it continued to publish four issues per year, until 1974, when it began to publish six issues per year. Figure 1 shows the evolution and number of articles published in LRP.

It is observed from this figure that the average number of publications in LRP increased in 1974, although there was also an important decrease in the number of articles in 2000. It is important to highlight some years in which a large number of publications were produced. For example, the most articles were published in 1989, totalling 93. In contrast, 2012 saw the lowest number of articles published (17), second only to 1968 . To analyze the number of publications and the citation structure of LRP, Table 1 shows the number of articles published in the journal annually as well as the total number of citations received by them. 


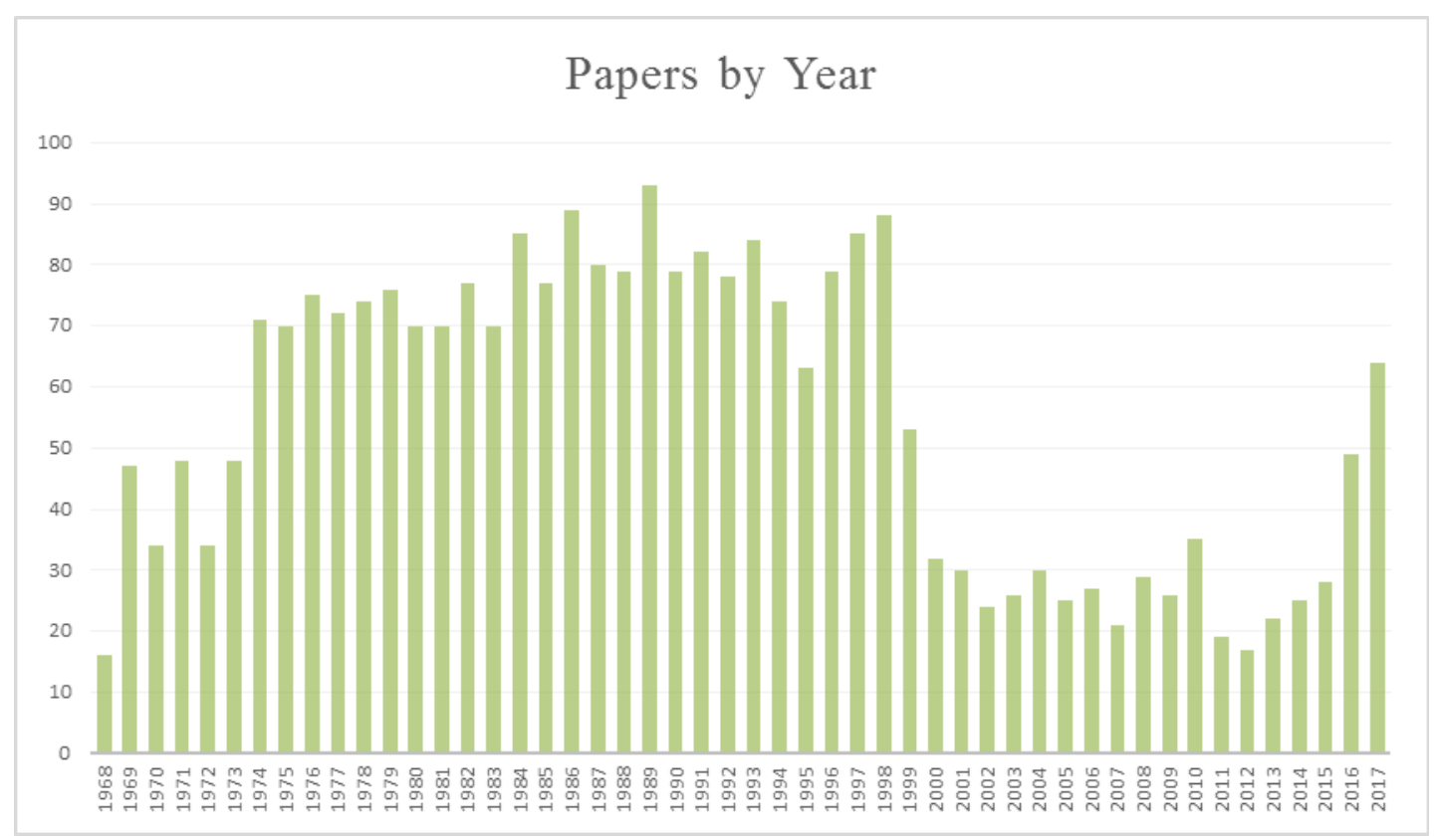

Figure 1 Annual number of papers published in LRP Source: The authors

This table confirms what was previously described. Between 1974 and 1998, LRP averaged 78 articles per year. In the following years, its average number of published papers decreased to 27 articles per year. The journal's citation structure shows us quite interesting data. For example, 1998 is the year in which articles have accumulated the most citations. However, other years such as 1997 and 2002 have been equally important in terms of the accumulation of citations. Some of the most cited authors in these years are, for example, Edvinsson L., Gray ER., Balmer JMT., and Grant RM., among several others. Also note that 2010 is especially relevant, as several of the articles published during that year have been especially influential.

\subsubsection{Influential papers in LRP}

LRP has published several documents that have led different lines of research in the field of strategic management. Therefore, these documents have been cited by a wide range of articles published in different Business and Management journals. In this sense, it is important to analyze the most cited articles in the journal. Table 2 presents the fifty most cited LRP articles.
The indicators presented are the year in which the article was published, total citations (TC) and the ratio of citations per year $(\mathrm{C} / \mathrm{Y})$.

Teece D.J. is the author who published the most cited article in LRP, with 1,290 citations. The early success of this article lies in its goal, which is to help understand the importance of business models and explore their connections to business strategy, innovation management, and economic theory. Another very influential article from LRP by Nonaka, Toyama and Konno has received 1,195 citations. This article helps to understand the dynamic process in which an organization creates, maintains, and exploits knowledge. An interesting aspect to highlight is the repeated appearance of some authors in this ranking, which coincide with two of the recently mentioned authors, namely, Teece and Nonaka, with two documents each. Finally, it is important to highlight the articles that have the ratio with the highest citations per year. In this context, we highlight the document published in 2010 by Teece, which receives approximately 161 citations per year. 
Table 1 Annual citation structure of LRP

\begin{tabular}{|c|c|c|c|c|c|c|c|c|c|c|}
\hline Year & TP & TC & $>200$ & $>150$ & $>100$ & $>50$ & $>20$ & $>10$ & $>5$ & $>1$ \\
\hline 1968 & 16 & 17 & 0 & 0 & 0 & 0 & 0 & 0 & 1 & 3 \\
\hline 1969 & 47 & 51 & 0 & 0 & 0 & 0 & 0 & 1 & 3 & 11 \\
\hline 1970 & 34 & 109 & 0 & 0 & 0 & 1 & 1 & 1 & 3 & 8 \\
\hline 1971 & 48 & 42 & 0 & 0 & 0 & 0 & 0 & 1 & 1 & 7 \\
\hline 1972 & 34 & 79 & 0 & 0 & 0 & 0 & 0 & 1 & 4 & 15 \\
\hline 1973 & 48 & 72 & 0 & 0 & 0 & 0 & 0 & 1 & 3 & 14 \\
\hline 1974 & 71 & 115 & 0 & 0 & 0 & 0 & 1 & 1 & 2 & 20 \\
\hline 1975 & 70 & 200 & 0 & 0 & 0 & 1 & 2 & 6 & 7 & 18 \\
\hline 1976 & 75 & 157 & 0 & 0 & 0 & 0 & 0 & 3 & 9 & 25 \\
\hline 1977 & 72 & 236 & 0 & 0 & 0 & 1 & 1 & 4 & 13 & 30 \\
\hline 1978 & 74 & 211 & 0 & 0 & 0 & 0 & 3 & 6 & 7 & 22 \\
\hline 1979 & 76 & 241 & 0 & 0 & 0 & 0 & 3 & 7 & 11 & 31 \\
\hline 1980 & 70 & 179 & 0 & 0 & 0 & 0 & 1 & 3 & 9 & 24 \\
\hline 1981 & 70 & 286 & 0 & 0 & 0 & 2 & 3 & 6 & 12 & 28 \\
\hline 1982 & 77 & 436 & 0 & 0 & 1 & 1 & 4 & 9 & 10 & 27 \\
\hline 1983 & 70 & 320 & 0 & 0 & 0 & 0 & 3 & 9 & 15 & 34 \\
\hline 1984 & 85 & 557 & 0 & 0 & 1 & 3 & 4 & 7 & 13 & 50 \\
\hline 1985 & 77 & 399 & 0 & 0 & 0 & 1 & 4 & 11 & 23 & 42 \\
\hline 1986 & 89 & 326 & 0 & 0 & 0 & 0 & 3 & 8 & 12 & 43 \\
\hline 1987 & 80 & 879 & 1 & 2 & 2 & 4 & 7 & 11 & 22 & 47 \\
\hline 1988 & 79 & 733 & 0 & 0 & 1 & 4 & 7 & 9 & 22 & 44 \\
\hline 1989 & 93 & 488 & 0 & 0 & 0 & 1 & 2 & 11 & 19 & 59 \\
\hline 1990 & 79 & 1028 & 0 & 0 & 1 & 4 & 11 & 19 & 31 & 56 \\
\hline 1991 & 82 & 961 & 0 & 0 & 0 & 5 & 12 & 27 & 40 & 57 \\
\hline 1992 & 78 & 840 & 0 & 0 & 1 & 1 & 10 & 19 & 32 & 55 \\
\hline 1993 & 84 & 1078 & 0 & 0 & 0 & 4 & 16 & 29 & 40 & 67 \\
\hline 1994 & 74 & 1218 & 0 & 0 & 0 & 7 & 15 & 30 & 41 & 61 \\
\hline 1995 & 63 & 965 & 0 & 0 & 1 & 4 & 14 & 18 & 30 & 49 \\
\hline 1996 & 79 & 1245 & 2 & 2 & 3 & 7 & 16 & 30 & 45 & 69 \\
\hline 1997 & 85 & 1747 & 5 & 7 & 8 & 13 & 30 & 47 & 60 & 77 \\
\hline 1998 & 88 & 2491 & 1 & 1 & 2 & 8 & 23 & 35 & 50 & 72 \\
\hline 1999 & 53 & 748 & 0 & 0 & 0 & 1 & 9 & 20 & 33 & 43 \\
\hline 2000 & 32 & 952 & 2 & 2 & 2 & 7 & 15 & 23 & 26 & 30 \\
\hline 2001 & 30 & 1012 & 1 & 3 & 5 & 9 & 14 & 21 & 27 & 29 \\
\hline 2002 & 24 & 1850 & 0 & 0 & 3 & 6 & 18 & 23 & 24 & 24 \\
\hline 2003 & 26 & 1149 & 0 & 0 & 2 & 5 & 15 & 19 & 23 & 26 \\
\hline 2004 & 30 & 1242 & 0 & 0 & 1 & 6 & 17 & 24 & 26 & 30 \\
\hline 2005 & 25 & 1323 & 0 & 0 & 2 & 7 & 12 & 21 & 25 & 25 \\
\hline 2006 & 27 & 1073 & 0 & 0 & 1 & 7 & 15 & 21 & 23 & 26 \\
\hline 2007 & 21 & 953 & 0 & 0 & 1 & 4 & 10 & 14 & 19 & 20 \\
\hline 2008 & 29 & 1036 & 0 & 0 & 0 & 2 & 15 & 22 & 27 & 29 \\
\hline 2009 & 26 & 739 & 0 & 0 & 0 & 3 & 10 & 18 & 21 & 26 \\
\hline 2010 & 35 & 928 & 8 & 11 & 14 & 18 & 29 & 32 & 35 & 35 \\
\hline 2011 & 19 & 588 & 0 & 0 & 0 & 4 & 9 & 13 & 18 & 18 \\
\hline 2012 & 17 & 334 & 0 & 2 & 2 & 3 & 5 & 10 & 13 & 17 \\
\hline 2013 & 22 & 558 & 0 & 0 & 1 & 3 & 8 & 16 & 19 & 22 \\
\hline 2014 & 25 & 481 & 0 & 0 & 0 & 1 & 7 & 11 & 17 & 25 \\
\hline 2015 & 28 & 222 & 0 & 0 & 0 & 0 & 2 & 7 & 10 & 24 \\
\hline 2016 & 49 & 276 & 0 & 0 & 0 & 1 & 1 & 1 & 6 & 27 \\
\hline 2017 & 64 & 136 & 0 & 0 & 0 & 0 & 0 & 0 & 1 & 14 \\
\hline Total & 2749 & 33306 & 20 & 30 & 55 & 159 & 407 & 686 & 983 & 1655 \\
\hline Percentage & $100 \%$ & & $0.73 \%$ & $1.09 \%$ & $2.00 \%$ & $5.78 \%$ & $14.81 \%$ & $24.95 \%$ & $35.76 \%$ & $60.20 \%$ \\
\hline
\end{tabular}

Abbreviations: TP and TC $=$ Total papers and citations; $\geq 100, \geq 50, \geq 20, \geq 10, \geq 5, \geq 1=$ Number of papers with equal or more than $100,50,20,10,5$ and 1 citations.

Source: The authors

\subsubsection{The documents most frequently cited in LRP publications}

Knowing the references most cited by documents published in LRP makes it possible to identify the most influential authors and documents among those who publish in LRP. Table 3 presents the 30 most cited documents in the journal's publications. Note that these documents may be of different types, which are distinguished in the table by an A or a B depending on whether it is an article or a book, respectively. 
Table 2 The 50 most cited documents in LRP

\begin{tabular}{|c|c|c|c|c|c|}
\hline $\mathbf{R}$ & Title & Author/s & Year & $\mathrm{TC}$ & $\mathrm{C} / \mathrm{Y}$ \\
\hline 1 & Business Models, Business Strategy and Innovation & Teece, DJ & 2010 & 1290 & 161,25 \\
\hline 2 & $\begin{array}{l}\text { SECl, ba and leadership: a unified model of dynamic } \\
\text { knowledge creation }\end{array}$ & Nonaka, l; Toyama, R; Konno, N & 2000 & 1195 & 66,39 \\
\hline 3 & Business Model Innovation: Opportunities and Barriers & Chesbrough, $\mathrm{H}$ & 2010 & 699 & 87,38 \\
\hline 4 & Business Model Design: An Activity System Perspective & Zott, C; Amit, R & 2010 & 564 & 70,50 \\
\hline 5 & From Strategy to Business Models and onto Tactics & Casadesus-Masanell, R; Ricart, JE & 2010 & 424 & 53,00 \\
\hline 6 & Developing intellectual capital at Skandia & Edvinsson, $\mathrm{L}$ & 1997 & 409 & 20,45 \\
\hline 7 & How corporate social responsibility pays off & Burke, L; Logsdon, JM & 1996 & 400 & 19,05 \\
\hline 8 & $\begin{array}{l}\text { Strategies for managing knowledge assets: the role of firm } \\
\text { structure and industrial context }\end{array}$ & Teece, DJ & 2000 & 369 & 20,50 \\
\hline 9 & Project success: A multidimensional strategic concept & Shenhar, AJ; Dvir, D; Levy, O; Maltz, AC & 2001 & 362 & 21,30 \\
\hline 10 & Measuring your company's intellectual performance & Roos, G; Roos, J & 1997 & 356 & 17,80 \\
\hline 11 & $\begin{array}{l}\text { Business Model Evolution: In Search of Dynamic } \\
\text { Consistency }\end{array}$ & Demil, B; Lecocq, X & 2010 & 345 & 43,13 \\
\hline 12 & Business Models as Models & Baden-Fuller, C; Morgan, MS; & 2010 & 312 & 39,00 \\
\hline 13 & $\begin{array}{l}\text { The new marketing - Developing long-term interactive } \\
\text { relationships }\end{array}$ & Gummesson, E & 1987 & 305 & 10,17 \\
\hline 14 & Managing corporate image and corporate reputation & Gray, ER; Balmer, JMT & 1998 & 282 & 14,84 \\
\hline 15 & Strategy as practice & Whittington, $R$ & 1996 & 280 & 13,33 \\
\hline 16 & SWOT analysis: It's time for a product recall & Hill, T; Westbrook, R & 1997 & 274 & 13,70 \\
\hline 17 & $\begin{array}{l}\text { Partial Least Squares Structural Equation Modeling: } \\
\text { Rigorous Applications, Better Results and Higher } \\
\text { Acceptance } \\
\end{array}$ & Hair, JF., Jr.; Ringle, CM.; Sarstedt, M & 2013 & 272 & 54,50 \\
\hline 18 & $\begin{array}{l}\text { Building Social Business Models: Lessons from the } \\
\text { Grameen Experience }\end{array}$ & $\begin{array}{l}\text { Yunus, M; Moingeon, B; Lehmann-Ortega, } \\
\text { L }\end{array}$ & 2010 & 272 & 34,00 \\
\hline 19 & Business Models: A Discovery Driven Approach & McGrath, RG & 2010 & 267 & 33,34 \\
\hline 20 & $\begin{array}{l}\text { The Use of Partial Least Squares Structural Equation } \\
\text { Modeling in Strategic Management Research: A Review of } \\
\text { Past Practices and Recommendations for Future } \\
\text { Applications }\end{array}$ & $\begin{array}{l}\text { Hair, JF.; Sarstedt, M; Pieper, TM; Ringle, } \\
\text { CM }\end{array}$ & 2012 & 254 & 43,33 \\
\hline 21 & $\begin{array}{l}\text { Hierarchical Latent Variable Models in PLS-SEM: Guidelines } \\
\text { for Using Reflective-Formative Type Models }\end{array}$ & Becker, JM; Klein, K; Wetzels, M & 2012 & 236 & 28,67 \\
\hline 22 & $\begin{array}{l}\text { The knowledge based view of the firm: Implications for } \\
\text { management practice }\end{array}$ & Grant, RM & 1997 & 233 & 39,33 \\
\hline 23 & Understanding knowledge management & Demarest, $\mathrm{M}$ & 1997 & 230 & 11,50 \\
\hline 24 & $\begin{array}{l}\text { Sustainability in action: Identifying and measuring the key } \\
\text { performance drivers }\end{array}$ & Epstein, MJ; Roy, MJ & 2001 & 226 & 13,30 \\
\hline 25 & $\begin{array}{l}\text { Business Model Innovation through Trial-and-Error Learning } \\
\text { The Naturhouse Case }\end{array}$ & \begin{tabular}{|l} 
Sosna, M; $\quad$ Trevinyo-Rodriguez, RN; \\
Velamuri, SR
\end{tabular} & 2010 & 225 & 28,13 \\
\hline 26 & Integrating intellectual capital and knowledge management & Wiig, KM & 1997 & 214 & 10,70 \\
\hline 27 & 5 stages of growth in small business & Scott, M; Bruce, R & 1987 & 209 & 6,97 \\
\hline 28 & $\begin{array}{l}\text { Embedding Strategic Agility A Leadership Agenda for } \\
\text { Accelerating Business Model Renewal }\end{array}$ & Doz, YL; Kosonen, M & 2010 & 198 & 24,75 \\
\hline 29 & $\begin{array}{l}\text { Success factors of strategic alliances in small and medium- } \\
\text { sized enterprises - An empirical survey }\end{array}$ & Hoffmann, WH; Schlosser, R & 2001 & 174 & 10,23 \\
\hline 30 & Business Models and Technological Innovation & Baden-Fuller, C; Haefliger, S & 2013 & 172 & 34,40 \\
\hline 31 & $\begin{array}{l}\text { Strategic Development of Business Models Implications of } \\
\text { the Web 2.0 for Creating Value on the Internet }\end{array}$ & Wirtz, BW; Schilke, O; Ullrich, S & 2010 & 171 & 21,38 \\
\hline 32 & Knowledge management: A strategic agenda & Quintas, P; Lefrere, P; Jones, G & 1997 & 168 & 7,62 \\
\hline 33 & The tows matrix - A tool for situational analysis & Weihrich, $\mathrm{H}$ & 1982 & 167 & 4,64 \\
\hline 34 & $\begin{array}{l}\text { Making the most of your company's knowledge: A strategic } \\
\text { framework }\end{array}$ & von Krogh, G; Nonaka, I; Aben, M & 2001 & 162 & 9,60 \\
\hline 35 & $\begin{array}{l}\text { Business-Model Innovation: General Purpose Technologies } \\
\text { and their Implications for Industry Structure }\end{array}$ & Gambardella, A; McGahan, AM & 2010 & 158 & 19,75 \\
\hline 36 & Core competence: What does it mean in practice? & Javidan, M & 1998 & 157 & 8,26 \\
\hline 37 & $\begin{array}{l}\text { Failing to learn and learning to fail (Intelligently): How great } \\
\text { organizations put failure to work to innovate and improve }\end{array}$ & Cannon, MD; Edmondson, AC & 2005 & 151 & 11,62 \\
\hline 38 & $\begin{array}{l}\text { Building alliance capability: Management techniques for } \\
\text { superior alliance performance }\end{array}$ & Draulans, J; deMan, AP; Volberda, HW & 2003 & 150 & 10,00 \\
\hline 39 & $\begin{array}{l}\text { Corporate-NGO Collaboration: Co-creating New Business } \\
\text { Models for Developing Markets }\end{array}$ & Dahan, NM; Doh, JP; Oetzel, J; Yaziji, M & 2010 & 149 & 18,63 \\
\hline 40 & $\begin{array}{l}\text { Proactive corporate environmental strategies: Myths and } \\
\text { misunderstandings }\end{array}$ & Aragon-Correa, JA; Rubio-Lopez, EA & 2007 & 145 & 14,50 \\
\hline 41 & $\begin{array}{l}\text { Strategic corporate social responsibility and value creation } \\
\text { among large firms - Lessons from the Spanish experience }\end{array}$ & Husted, BW; Allen, DB & 2007 & 142 & 12,90 \\
\hline
\end{tabular}




\begin{tabular}{c|l|l|c|c|c}
\hline 42 & Tacit knowledge and environmental management & Boiral, O & 2002 & 142 & 8,88 \\
\hline 43 & $\begin{array}{l}\text { Offshoring work: Business hype or the onset of fundamental } \\
\text { transformation? }\end{array}$ & 2006 & 141 & 11,75 \\
\hline 44 & $\begin{array}{l}\text { Complex Business Models: Managing Strategic Paradoxes AY; Peeters, C } \\
\text { Simultaneously }\end{array}$ & Smith, WK; Binns, A; Tushman, ML & 2010 & 139 & 17,38 \\
\hline 45 & Identifying and using critical success factors & Leidecker, JK; Bruno, AV & 1984 & 138 & 4,06 \\
\hline 46 & The management of innovation in project-based firms & Keegan, A; Turner, JR & 2002 & 137 & 8,56 \\
\hline 47 & Managing strategic change - Strategy, culture and action & Johnson, G & 1992 & 128 & 4,92 \\
\hline 48 & Creating the future: The use and misuse of scenarios & Godet, M; Roubelat, F & 1996 & 126 & 5,72 \\
\hline 49 & Deciding on ISO 14001: Economics, institutions, and context & Bansal, P; Bogner, WC & 2002 & 123 & 7,70 \\
\hline 50 & Strategic alliances - Choose your partners & $\begin{array}{l}\text { Brouthers, KD; Brouthers, LE; Wilkinson, } \\
\text { TJ }\end{array}$ & 1995 & 120 & 5,22 \\
\hline
\end{tabular}

Abbreviations: $\mathrm{R}=$ Rank; $\mathrm{TC}=$ Total citations; $\mathrm{C} / \mathrm{Y}$ Cites per years.

Table 3 Top 30 most cited documents in LRP publications

\begin{tabular}{|c|c|c|c|c|c|c|c|c|}
\hline Rank & Year & First author & Source Title & Vol. & Page & Type & $\mathrm{TC}$ & Co-cit \\
\hline 1 & 1980 & Porter ME & Competitive Strategy & & & $B$ & 148 & 80 \\
\hline 2 & 1985 & Porter ME & Competitive Advantag & & & $B$ & 86 & 59 \\
\hline 3 & 1991 & Barney J & J Manage & V17 & P99 & $A$ & 73 & 71 \\
\hline 4 & 1965 & Ansoff HI & Corporate Strategy & & & $\mathrm{B}$ & 59 & 32 \\
\hline 5 & 1989 & Eisenhardt KM & Acad Manage Rev & V14 & P532 & A & 59 & 56 \\
\hline 6 & 1982 & Peters T & Search Of Excellence & & & $B$ & 57 & 31 \\
\hline 7 & 1994 & Hamel G & Competing Future & & & $\mathrm{B}$ & 48 & 33 \\
\hline 8 & 1982 & Nelson RR & Evolutionary Theory & & & $\mathrm{B}$ & 48 & 43 \\
\hline 9 & 1990 & Cohen WM & Admin Sci Quart & V35 & P128 & $A$ & 47 & 41 \\
\hline 10 & 1997 & Teece DJ & Strategic Manage $\mathrm{J}$ & V18 & P509 & A & 47 & 44 \\
\hline 11 & 1991 & March JG & Organ Sci & V2 & P71 & $\mathrm{A}$ & 46 & 45 \\
\hline 12 & 1963 & March JG & Behav Theory Firm & & & $\mathrm{B}$ & 44 & 39 \\
\hline 13 & 1984 & Wernerfelt B & Strategic Manage J & V5 & P171 & A & 41 & 40 \\
\hline 14 & 1995 & Nonaka I & Knowledge Creating C & & & $\mathrm{B}$ & 36 & 32 \\
\hline 15 & 1993 & Levinthal DA & Strategic Manage J & V14 & P95 & $\mathrm{A}$ & 33 & 30 \\
\hline 16 & 2003 & Podsakoff PM & J Appl Psychol & V88 & P879 & A & 33 & 30 \\
\hline 17 & 1967 & Thompson J & Org Action & & & $B$ & 33 & 24 \\
\hline 18 & 1959 & Penrose ET & Theory Growth Firm & & & $\mathrm{B}$ & 32 & 30 \\
\hline 19 & 1992 & Kogut B & Organ Sci & V3 & P383 & A & 31 & 31 \\
\hline 20 & 1970 & Ackoff RL & Concept Corporate PI & & & $B$ & 30 & 13 \\
\hline 21 & 1990 & Prahalad CK & Harvard Bus Rev & V68 & P79 & $\mathrm{A}$ & 30 & 29 \\
\hline 22 & 1962 & Chandler AD & Strategy Structure C & & & $\mathrm{B}$ & 29 & 20 \\
\hline 23 & 2000 & Eisenhardt KM & Strategic Manage J & V21 & P1105 & $\mathrm{A}$ & 29 & 29 \\
\hline 24 & 1994 & Miles MB & Qualitative Data Ana & & & $\mathrm{B}$ & 29 & 28 \\
\hline 25 & 1994 & Mintzberg $\mathrm{H}$ & Rise Fall Strategic & & & $\mathrm{B}$ & 29 & 18 \\
\hline 26 & 1975 & Williamson OE & Markets Hierarchies & & & $\mathrm{B}$ & 29 & 22 \\
\hline 27 & 1978 & Hofer C & Strategy Formulation & & & $\mathrm{B}$ & 28 & 13 \\
\hline 28 & 1992 & Leonardbarton D & Strategic Manage J & V13 & P111 & $\mathrm{A}$ & 28 & 27 \\
\hline 29 & 1969 & Steiner G & Top Management Plann & & & $\mathrm{B}$ & 28 & 16 \\
\hline 30 & 1962 & Chandler A & Strategy structure & & & $\mathrm{B}$ & 26 & 17 \\
\hline
\end{tabular}

Abbreviations: Vol. = Volume; $\mathrm{TC}=$ Total citations; Co-cit = Co-citations; $\mathrm{B}=$ Book; $\mathrm{A}=$ Article

Source: The authors

Porter is the most cited author among LRP publications. In fact, his books "Competitive Strategy" and "Competitive Advantage" occupy the top positions in this list. March, J.G. and Eisenhardt, K.M. are other authors that appear more than once in this list. Also interesting is that $60 \%$ of the documents most cited in LRP are books and not articles, unlike other journals.

\subsubsection{Leading authors in LRP}

LRP has published a large number of articles by authors from different countries. Several of them have led and influenced not only the field of strategic management but also the publications produced by LRP. In this regard, Table 4 presents a list of the 50 most productive authors in the journal. To obtain an overall picture of each author's results, Table 4 considers several bibliometric indicators including the number of articles (TP), number of citations (TC), h-index $(\mathrm{H})$ and citations per article (TC/TP). Please also note that only the last/current affiliation of the corresponding author is included. 
Table 4 Top 50 leading authors in LRP

\begin{tabular}{|c|c|c|c|c|c|c|c|c|c|c|}
\hline $\mathbf{R}$ & Authors & Organization & Country & TP & TC & H & $\mathrm{C} / \mathrm{P}$ & $>100$ & $>50$ & $>10$ \\
\hline 1 & Andrew Campbell & Ashridge Strat Manage Cent & UK & 32 & 312 & 10 & 9,75 & 0 & 1 & 8 \\
\hline 2 & David E Hussey & Nottingham Trent U & UK & 30 & 37 & 3 & 1,23 & 0 & 0 & 1 \\
\hline 3 & Michaek Goold & Ashridge Strat Manage Cent & UK & 24 & 168 & 8 & 7 & 0 & 0 & 6 \\
\hline 4 & Bernard Taylor & U Reading & UK & 20 & 131 & 7 & 6,55 & 0 & 0 & 5 \\
\hline 5 & Henk W. Volberda & Erasmus U & Nether & 11 & 439 & 9 & 39,91 & 1 & 3 & 9 \\
\hline 6 & Carol Kennedy & Director Magazine & UK & 11 & 41 & 4 & 3,73 & 0 & 0 & 3 \\
\hline 7 & Brian Burrows & Futures Associates & UK & 10 & 14 & 2 & 1,4 & 0 & 0 & 0 \\
\hline 8 & William R. King & U Pittsburgh, Pennsylvania & USA & 9 & 227 & 6 & 25,22 & 0 & 3 & 5 \\
\hline 9 & Philippe Lasserre & INSEAD Fontainebleau & France & 9 & 92 & 4 & 10,22 & 0 & 1 & 2 \\
\hline 10 & Christopher J. Clarke & Henley Management College & UK & 9 & 60 & 3 & 6,67 & 0 & 0 & 1 \\
\hline 11 & Harvey Kahalas & State U New York at Albany & USA & 9 & 8 & 2 & 0,89 & 0 & 0 & 0 \\
\hline 12 & Charles Baden-Fuller & City U & UK & 8 & 626 & 8 & 78,25 & 2 & 4 & 8 \\
\hline 13 & Frans AJ van den Bosch & Erasmus U & Nether & 8 & 239 & 7 & 29,88 & 0 & 1 & 7 \\
\hline 14 & Alexander McKelvie & Syracuse U & USA & 8 & 118 & 4 & 14,75 & 0 & 0 & 4 \\
\hline 15 & Merlin Stone & Kingston Polytech & UK & 8 & 86 & 4 & 10,75 & 0 & 1 & 1 \\
\hline 16 & Roland Calori & Inst Rech l'Enterprise & France & 8 & 36 & 3 & 4,5 & 0 & 0 & 1 \\
\hline 17 & André Van Dam & Bedford Construction Co & Argen & 8 & 7 & 2 & 0,88 & 0 & 0 & 0 \\
\hline 18 & Sandra Vandermerwe & U Pretoria & S Africa & 7 & 126 & 5 & 18 & 0 & 1 & 2 \\
\hline 19 & Loizos Heracleous & Warwick Business School & USA & 7 & 116 & 4 & 16,57 & 0 & 1 & 3 \\
\hline 20 & D. Jan Eppink & Free U & Nether & 7 & 69 & 4 & 9,86 & 0 & 0 & 1 \\
\hline 21 & Toyohiro Kono & Gakushuin U & Japan & 7 & 46 & 5 & 6,57 & 0 & 0 & 2 \\
\hline 22 & Giorgio Petroni & Padua U & Italy & 7 & 28 & 3 & 4 & 0 & 0 & 1 \\
\hline 23 & Richard Whittington & U Oxford & UK & 6 & 426 & 4 & 71 & 1 & 3 & 3 \\
\hline 24 & Keith D. Brouthers & U East London & UK & 6 & 232 & 6 & 38,67 & 1 & 2 & 4 \\
\hline 25 & Howard Thomas & Warwick Business School & USA & 6 & 46 & 4 & 7,67 & 0 & 0 & 1 \\
\hline 26 & Sypros Makridakis & INSEAD Fontainebleau & France & 6 & 25 & 3 & 4,17 & 0 & 0 & 0 \\
\hline 27 & Clark Holloway & U South Carolina & USA & 6 & 20 & 3 & 3,33 & 0 & 0 & 0 \\
\hline 28 & Graham Turner & Nestlé S.A & Switz & 6 & 4 & 1 & 0,67 & 0 & 0 & 0 \\
\hline 29 & Johan Roos & Imagination Lab Foundation & Switz & 5 & 480 & 5 & 96 & 1 & 2 & 5 \\
\hline 30 & Bern W. Wirtz & German U Adm Sci Speyer & Germany & 5 & 312 & 4 & 62,4 & 1 & 3 & 4 \\
\hline 31 & Georg von Krogh & ETH Zurich & Switz & 5 & 290 & 4 & 58 & 1 & 2 & 4 \\
\hline 32 & Leif Melin & Jönköping U & Sweden & 5 & 107 & 4 & 21,4 & 0 & 1 & 3 \\
\hline 33 & Ian Wilson & Wolf Enterprises & USA & 5 & 89 & 5 & 17,8 & 0 & 0 & 2 \\
\hline 34 & Philip Stiles & U Cambridge & UK & 5 & 79 & 4 & 15,8 & 0 & 0 & 2 \\
\hline 35 & Peter Lorange & Nestlé S.A & Switz & 5 & 70 & 3 & 14 & 0 & 0 & 2 \\
\hline 36 & Peter H Grinyer & U St Andrews & UK & 5 & 60 & 4 & 12 & 0 & 0 & 2 \\
\hline 37 & Sue Birley & Imperial College & UK & 5 & 52 & 3 & 10,4 & 0 & 0 & 1 \\
\hline 38 & Mike Wright & Nottingham U & UK & 5 & 41 & 3 & 8,2 & 0 & 0 & 2 \\
\hline 39 & Johan G. Wissema & Wissema Group & Nether & 5 & 31 & 2 & 6,2 & 0 & 0 & 1 \\
\hline 40 & Richard B. Higgins & Northeastern U & USA & 5 & 26 & 3 & 5,2 & 0 & 0 & 1 \\
\hline 41 & Tony Grundy & City U Business School & USA & 5 & 20 & 3 & 4 & 0 & 0 & 0 \\
\hline 42 & Brian T. Houlden & Warwick Business School & USA & 5 & 15 & 2 & 3 & 0 & 0 & 0 \\
\hline 43 & George F. Ray & National Inst Econ Social Res & UK & 5 & 9 & 1 & 1,8 & 0 & 0 & 0 \\
\hline 44 & Roger W. Mills & Henley Management College & UK & 5 & 5 & 1 & 1 & 0 & 0 & 0 \\
\hline 45 & Siegfried Höhn & Volkswagen AG & Germany & 5 & 3 & 1 & 0,6 & 0 & 0 & 0 \\
\hline 46 & Robert M. Grant & Bocconi U & Italy & 4 & 245 & 3 & 61.25 & 1 & 1 & 2 \\
\hline 47 & Keith W. Glaister & U Leeds & UK & 4 & 112 & 4 & 28 & 0 & 1 & 3 \\
\hline 48 & Colin Eden & Strathclyde U & UK & 4 & 110 & 4 & 27.5 & 0 & 1 & 2 \\
\hline 49 & Stephen Cummings & Victoria U Wellington & N Zealand & 4 & 102 & 4 & 25.5 & 0 & 0 & 4 \\
\hline 50 & H. Igor Ansoff & US Int U in San Diego & USA & 4 & 58 & 3 & 14,5 & 0 & 0 & 2 \\
\hline
\end{tabular}

Abbreviations are available in Tables 1 and 2 except for: $\mathrm{H}=h$-index; $\mathrm{C} / \mathrm{P}=$ Cites per paper.

Source: The authors

Note that Andrew Campbell is the most productive author in the magazine with 32 papers and an h-index of 10. David Hussey follows with
30 papers. However, other authors have achieved remarkable indicators of productivity and influence. Such is the case of Charles Baden- 
Fuller, who has 8 published papers and 626 citations. Note also that this author's h-index is 8 . In other words, all of this author's papers have been cited at least 8 times. It is also interesting to note that this author has the highest level of citations per article. Finally, keep in mind that a significant proportion of the authors who publish in LRP are European, with a large presence of authors from the UK.

\subsubsection{The most productive and influential institutions in LRP}

Another issue similar to the previous point, which is interesting to analyze, is to identify the institutions that have published the most and that have a great influence on LRP. These institutions are, in general, those in which the authors collaborate and develop their research. Table 5 shows the 50 most productive and influential institutions of the journal's 50 years. This table considers different performance indicators including total papers (TP), total citations (TC), hindex $(\mathrm{H})$ and the ratio of citations per papers (TC/TP). It also contains the number of papers per citation threshold of 100, 50 and 10. The Table also presents the current world ranking of these institutions according to the Academic Ranking of World Universities (ARWU) and the Quacquarelli Symonds World University Ranking (QS). The objective of using the last two indicators is to see the world ranking of the main universities publishing in LRP.

University of Warwick, Erasmus University Rotterdam and the University of Reading are the institutions leading productivity in LRP. However, the University of California at Berkeley is by far the journal's most influential institution. Other institutions that stand out in this line are the University of Pennsylvania and Harvard University, with more than one thousand citations each. It is important to point out that $40 \%$ of the universities on this list are from the UK. However, universities from the USA and European countries such as Netherlands, France, Denmark and Switzerland also appear. Institutions from other continental regions are rarely listed. It is also of note that many of the best universities have published in this journal. In fact, 21 of the 50 institutions appear among the top 100 universities in the world rankings. Nine of them, led by Harvard University and the University of Cambridge, are in the Top 20. From this perspective, LRP is a quite diverse and influential journal in the field of strategic management.

It is also interesting to follow and analyze temporally the productivity of the institutions during the fifty years of LRP. Table 6 shows a temporal analysis of the 30 institutions that have contributed the most to the development and positioning of the journal.

During the first decade of its existence, it is clear that contributions to LRP were mainly concentrated in three institutions. Of these, the University of Bradford has maintained an important level of contribution. It is also noted that over the last three decades, Erasmus University Rotterdam has led journal productivity. Finally, it can be observed that he University of Warwick has maintained a strong presence during the last four decades, which has allowed it to lead productivity during LRP's fifty years.

\subsubsection{The most productive and influential countries in LRP}

LRP has published works from a large number of countries, making it an internationally diverse magazine. Table 7 presents the 50 most productive and influential LRP countries. Please note that the country refers to the country in which the authors worked at the time their manuscript was published. In this list, the countries are classified according to their productivity, although influence indicators are also shown in Table 5. In addition, productivity indicators and citations are incorporated for each million inhabitants of the country.

The results in Table 7 confirm an increase in the multinationality of LRP. It can be seen that more than 50 countries have managed to publish in the magazine. The UK leads in productivity, with more than 870 documents published. However, the USA is the most influential country, with more than 14,000 citations and an h-index of 58. It should be noted, however, that countries such as the Netherlands or Canada, with considerably fewer publications, obtain a high level of citations in LRP compared to other countries. The citation thresholds also show that the USA has published most of the journal's most influential articles. In terms of productivity per person, small countries such as San Marino and 
Table 5 The most productive and influential institutions in LRP

\begin{tabular}{|c|c|c|c|c|c|c|c|c|c|c|c|}
\hline $\mathbf{R}$ & Organization & Country & TP & TC & $\mathrm{H}$ & $\mathrm{TC} / \mathrm{TP}$ & $>100$ & $>50$ & $>10$ & ARWU & QS \\
\hline 1 & U Warwick & UK & 40 & 515 & 14 & 12,88 & 0 & 0 & 18 & $101-150$ & 57 \\
\hline 2 & Erasmus U Rotterdam & Netherlands & 38 & 865 & 16 & 22,76 & 2 & 5 & 20 & 73 & 147 \\
\hline 3 & U Reading & UK & 37 & 407 & 12 & 11 & 0 & 2 & 14 & $201-300$ & 188 \\
\hline 4 & Ashridge Strat Manag & UK & 36 & 214 & 8 & 5,94 & 0 & 0 & 7 & - & - \\
\hline 5 & City U London & UK & 34 & 865 & 14 & 25,44 & 2 & 4 & 15 & - & 343 \\
\hline 6 & U Bradford & UK & 34 & 540 & 12 & 15,88 & 0 & 3 & 14 & - & $601-650$ \\
\hline 7 & U Manchester & UK & 29 & 174 & 7 & 6 & 0 & 0 & 7 & 38 & 34 \\
\hline 8 & London Business School & UK & 27 & 445 & 9 & 16,48 & 1 & 1 & 6 & - & 308 \\
\hline 9 & Int Inst Manag Devel & Switzerland & 25 & 823 & 10 & 32,92 & 2 & 3 & 10 & - & - \\
\hline 10 & U Cambridge & UK & 24 & 388 & 12 & 16,17 & 0 & 1 & 13 & 3 & 5 \\
\hline 11 & Cranfield U & UK & 23 & 416 & 9 & 18,09 & 1 & 2 & 9 & - & - \\
\hline 12 & INSEAD Business School & France & 23 & 321 & 8 & 13,96 & 1 & 2 & 4 & - & - \\
\hline 13 & National U Singapore & Singapore & 22 & 247 & 8 & 11,23 & 0 & 1 & 8 & 91 & 15 \\
\hline 14 & U Pennsylvania & USA & 21 & 1299 & 12 & 61,86 & 3 & 5 & 13 & 17 & 19 \\
\hline 15 & Cardiff U & UK & 21 & 301 & 10 & 14,33 & 0 & 2 & 8 & 99 & 137 \\
\hline 16 & Bocconi U & Italy & 20 & 493 & 12 & 24,65 & 1 & 2 & 12 & - & - \\
\hline 17 & Harvard U & USA & 18 & 1057 & 11 & 58,72 & 4 & 5 & 11 & 1 & 3 \\
\hline 18 & U Bath & UK & 18 & 271 & 5 & 15,06 & 1 & 2 & 5 & $501-600$ & 160 \\
\hline 19 & U Nottingham & UK & 18 & 243 & 10 & 13,5 & 0 & 1 & 8 & $101-150$ & 84 \\
\hline 20 & U Oxford & UK & 17 & 598 & 10 & 35,18 & 1 & 4 & 10 & 7 & 6 \\
\hline 21 & U Pittsburgh & USA & 17 & 282 & 8 & 16,59 & 0 & 3 & 6 & 68 & 142 \\
\hline 22 & Northeastern U & USA & 17 & 126 & 6 & 7,41 & 0 & 0 & 4 & $201-300$ & 346 \\
\hline 23 & Vrije U Amsterdam & Netherlands & 16 & 371 & 10 & 23,19 & 1 & 2 & 5 & $101-150$ & 218 \\
\hline 24 & Copenhagen Bus School & Denmark & 16 & 330 & 7 & 20,63 & 0 & 2 & 10 & $601-700$ & - \\
\hline 25 & Open U UK & UK & 14 & 319 & 7 & 22,79 & 1 & 2 & 6 & $601-700$ & - \\
\hline 26 & U St Gallen & Switzerland & 14 & 236 & 8 & 16,86 & 0 & 0 & 8 & - & 372 \\
\hline 27 & Temple U & USA & 14 & 184 & 9 & 13,14 & 0 & 0 & 6 & $301-400$ & $651-700$ \\
\hline 28 & Baruch College CUNY & USA & 13 & 323 & 8 & 24,85 & 0 & 3 & 7 & - & - \\
\hline 29 & Lancaster U & UK & 13 & 198 & 5 & 15,23 & 0 & 2 & 3 & $301-400$ & 135 \\
\hline 30 & Virginia Polytech Inst St U & USA & 13 & 104 & 5 & 8 & 0 & 1 & 3 & $301-400$ & 367 \\
\hline 31 & Loughborough U & UK & 13 & 71 & 4 & 5,46 & 0 & 0 & 1 & $601-700$ & 234 \\
\hline 32 & U Strathclyde & UK & 12 & 466 & 7 & 38,83 & 1 & 3 & 5 & - & 277 \\
\hline 33 & Columbia U & USA & 12 & 299 & 4 & 24,92 & 1 & 1 & 4 & 8 & 18 \\
\hline 34 & Int Bus Machines (IBM) & USA & 12 & 20 & 3 & 1,67 & 0 & 0 & 0 & - & - \\
\hline 35 & U California Berkeley & USA & 11 & 2416 & 8 & 219,64 & 5 & 6 & 8 & 5 & 27 \\
\hline 36 & U Western Ontario & Canada & 11 & 375 & 8 & 34,09 & 1 & 3 & 8 & - & 210 \\
\hline 37 & U Leeds & UK & 11 & 352 & 8 & 32 & 0 & 3 & 8 & $101-150$ & 101 \\
\hline 38 & Imperial College London & UK & 11 & 230 & 5 & 20,91 & 0 & 1 & 5 & 27 & 8 \\
\hline 39 & U Birmingham & UK & 11 & 92 & 5 & 8,36 & 0 & 0 & 3 & $101-150$ & 84 \\
\hline 40 & U Innsbruck & Austria & 11 & 70 & 3 & 6,36 & 0 & 0 & 2 & $151-200$ & 286 \\
\hline 41 & U California Los Angeles & USA & 10 & 223 & 5 & 22,3 & 1 & 1 & 5 & 12 & 33 \\
\hline 42 & Duke U & USA & 10 & 218 & 5 & 21,8 & 1 & 1 & 2 & 26 & 21 \\
\hline 43 & Boston U & USA & 10 & 158 & 7 & 15,8 & 0 & 0 & 6 & 80 & 81 \\
\hline 44 & U Hong Kong & PR China & 10 & 126 & 4 & 12,6 & 0 & 1 & 3 & $101-150$ & 26 \\
\hline 45 & Sri International & USA & 10 & 71 & 5 & 7,1 & 0 & 0 & 2 & - & - \\
\hline 46 & U Illinois Urbana Champ & USA & 10 & 56 & 4 & 5,6 & 0 & 0 & 2 & 37 & 69 \\
\hline 47 & BI Norwegian Bus Sch & Norway & 9 & 424 & 5 & 47,11 & 1 & 1 & 5 & - & - \\
\hline 48 & Polytechnic U Milan & Italy & 9 & 339 & 9 & 37.67 & 0 & 1 & 9 & $201-300$ & 170 \\
\hline 49 & Ohio State University & USA & 9 & 203 & 5 & 22.56 & 0 & 1 & 4 & 80 & 86 \\
\hline 50 & Aston U & UK & 9 & 153 & 5 & 17 & 0 & 1 & 4 & - & 373 \\
\hline
\end{tabular}

Abbreviations are available in Tables 1,2 and 4 except for: ARWU = Academic Ranking of World Universities; QS = Quacquarelli Symonds University Ranking. 
Table 6 Temporal analysis of 30 most contributing institutions

\begin{tabular}{|c|c|c|c|c|c|c|c|}
\hline & University & TP & TC & $\mathbf{R}$ & University & TP & TC \\
\hline \multicolumn{4}{|c|}{ 1968-1978 } & \multicolumn{4}{|c|}{$1999-2008$} \\
\hline 1 & U Bradford & 11 & 30 & 1 & Erasmus U Rotterdam & 16 & 621 \\
\hline 2 & U Manchester & 9 & 10 & 2 & U Warwick & 12 & 323 \\
\hline 3 & Virginia Polytechnic Inst St U & 9 & 4 & 3 & City U London & 9 & 272 \\
\hline \multicolumn{4}{|c|}{ 1979-1988 } & 4 & U Nottingham & 8 & 179 \\
\hline 1 & Harbridge House Europe & 16 & 5 & 5 & Harvard U & 7 & 502 \\
\hline 2 & U Reading & 13 & 80 & 6 & U Western Ontario & 7 & 304 \\
\hline 3 & U Manchester & 10 & 29 & 7 & U Bradford & 7 & 277 \\
\hline 4 & Loughborough U & 9 & 20 & 8 & U Pennsylvania & 7 & 249 \\
\hline 5 & U Bath & 8 & 149 & 9 & Bocconi U & 7 & 170 \\
\hline 6 & U Pittsburgh & 7 & 154 & 10 & U Cambridge & 7 & 153 \\
\hline 7 & U Bradford & 7 & 2 & 11 & U Reading & 6 & 180 \\
\hline 8 & U Minnesota Twin Cities & 6 & 88 & 12 & Cardiff U & 6 & 121 \\
\hline 9 & Cranfield U & 6 & 31 & \multicolumn{4}{|c|}{$2009-2017$} \\
\hline 10 & Sri International & 6 & 26 & 1 & Erasmus U Rotterdam & 13 & 130 \\
\hline 11 & U Warwick & 6 & 24 & 2 & City U London & 12 & 496 \\
\hline \multicolumn{4}{|c|}{ 1989-1998 } & 3 & Bocconi U & 12 & 316 \\
\hline 1 & Erasmus U Rotterdam & 16 & 615 & 4 & Copenhagen Business School & 12 & 259 \\
\hline 2 & U Warwick & 12 & 319 & 5 & U Cambridge & 10 & 176 \\
\hline 3 & City U London & 9 & 272 & 6 & U St Gallen & 9 & 81 \\
\hline 4 & U Nottingham & 8 & 177 & 7 & U Oxford & 9 & 50 \\
\hline 5 & Harvard U & 7 & 492 & 8 & U Pennsylvania & 8 & 972 \\
\hline 6 & U Western Ontario & 7 & 301 & 9 & Esade Business School & 8 & 137 \\
\hline 7 & U Bradford & 7 & 274 & 10 & Universitat Ramon Llull & 8 & 137 \\
\hline 8 & U Pennsylvania & 7 & 246 & 11 & ETH Zurich & 7 & 152 \\
\hline 9 & Bocconi U & 7 & 169 & 12 & U Warwick & 7 & 46 \\
\hline 10 & U Cambridge & 7 & 152 & 13 & U Innsbruck & 7 & 15 \\
\hline 11 & U Reading & 6 & 177 & 14 & U Reading & 6 & 97 \\
\hline 12 & Cardiff U & 6 & 120 & 15 & Lancaster U & 6 & 84 \\
\hline
\end{tabular}

Abbreviations are available in the previous tables.

Switzerland are the most productive. Similarly, the citation per person indicator again indicates that San Marino and Switzerland receive the best indicators. Other countries, such as the UK, the Netherlands and Norway, obtain outstanding results.

Table 8 shows the bibliometric indicators of LRP from a regional perspective. This table shows that European countries, led mainly by the UK, broadly dominate LRP productivity. European countries also obtain outstanding results in terms of influence, with indicators such as total citations or h-indexes higher than North America.

\subsubsection{Actors who most cite LRP}

Finally, in this performance analysis, we believe that it is valuable to identify the scientific actors who cite LRP publications most. Table 9 shows the authors, institutions, countries and journals that most frequently cite LRP.

From the table above, Henry W. Volberda is the most cited author of LRP publications. It should also be noted that this author is one of the ten most productive LRP authors. Along the same lines, the University of Manchester is the institution that cites the journal most. It is followed by the University of Warwick and Erasmus University Rotterdam. Curiously enough, the USA is the country that has cited LRP's work the most. However, one must keep in mind that the journal's work has been cited by very diverse countries, confirming the journal's growing multinationality and influence. Note that a large number of LRP articles cite articles published in the same magazine. LRP is a pioneer journal in strategic management, and has become consolidated and quite influential during these five decades, so it is normal that it has a high level of self-citation. Finally, an important aspect that validates and reinforces LRP is that journals from different areas and disciplines have cited its articles. 
Table 7 The most productive and influential countries in LRP

\begin{tabular}{|c|c|c|c|c|c|c|c|c|c|c|c|}
\hline $\mathbf{R}$ & Country & TP & TC & H & $\mathrm{TC} / \mathrm{TP}$ & $>100$ & $>50$ & $>10$ & Population & TP/POP & TC/POP \\
\hline 1 & UK & 873 & 9.123 & 46 & 10,45 & 9 & 39 & 210 & 65640000 & 13,30 & 138,99 \\
\hline 2 & USA & 754 & 14.916 & 58 & 19,78 & 29 & 68 & 237 & 324118787 & 2,33 & 46,02 \\
\hline 3 & Netherlands & 125 & 2.538 & 25 & 20,3 & 7 & 14 & 48 & 16979729 & 7,36 & 149,47 \\
\hline 4 & Canada & 107 & 2.062 & 22 & 19,27 & 5 & 15 & 37 & 36286378 & 2,95 & 56,83 \\
\hline 5 & Switzerland & 89 & 1.664 & 22 & 18,7 & 2 & 7 & 35 & 8379477 & 10,62 & 198,58 \\
\hline 6 & France & 78 & 1.472 & 15 & 18,87 & 5 & 7 & 21 & 64668129 & 1,21 & 22,76 \\
\hline 7 & Germany & 68 & 1.513 & 21 & 22,25 & 4 & 9 & 29 & 80682351 & 0,84 & 18,75 \\
\hline 8 & Italy & 61 & 1.005 & 17 & 16,48 & 1 & 4 & 24 & 59801004 & 1,02 & 16,81 \\
\hline 9 & Japan & 50 & 1.464 & 11 & 29,28 & 1 & 2 & 11 & 126323715 & 0,40 & 11,59 \\
\hline 10 & Australia & 49 & 563 & 12 & 11,49 & 0 & 4 & 12 & 24309330 & 2,02 & 23,16 \\
\hline 11 & PR China & 45 & 621 & 13 & 13,8 & 1 & 2 & 9 & 1382323332 & 0,03 & 0,45 \\
\hline 12 & India & 44 & 159 & 6 & 3,61 & 0 & 0 & 5 & 1326801576 & 0,03 & 0,12 \\
\hline 13 & Belgium & 34 & 511 & 12 & 15,03 & 1 & 3 & 13 & 11371928 & 2,99 & 44,94 \\
\hline 14 & Singapore & 32 & 347 & 12 & 10,84 & 0 & 1 & 12 & 5696506 & 5,62 & 60,91 \\
\hline 15 & Spain & 31 & 1.435 & 11 & 46,29 & 4 & 5 & 13 & 46064604 & 0,67 & 31,15 \\
\hline 16 & Austria & 26 & 452 & 9 & 17,38 & 1 & 2 & 7 & 8747000 & 2,97 & 51,67 \\
\hline 17 & Sweden & 25 & 534 & 7 & 21,36 & 1 & 3 & 5 & 9851852 & 2,54 & 54,20 \\
\hline 18 & Denmark & 24 & 411 & 11 & 17,13 & 0 & 2 & 11 & 5690750 & 4,22 & 72,22 \\
\hline 19 & New Zealand & 22 & 193 & 9 & 8,77 & 0 & 0 & 6 & 4565185 & 4,82 & 42,28 \\
\hline 20 & Norway & 19 & 539 & 9 & 28,37 & 1 & 2 & 9 & 5271958 & 3,60 & 102,24 \\
\hline 21 & South Korea & 19 & 129 & 7 & 6,79 & 0 & 0 & 2 & 50503933 & 0,38 & 2,55 \\
\hline 22 & South Africa & 18 & 304 & 6 & 16,89 & 1 & 2 & 2 & 54978907 & 0,33 & 5,53 \\
\hline 23 & Israel & 17 & 584 & 7 & 34,35 & 1 & 3 & 6 & 8192463 & 2,08 & 71,29 \\
\hline 24 & Ireland & 17 & 172 & 7 & 10,12 & 0 & 1 & 5 & 4713993 & 3,61 & 36,49 \\
\hline 25 & Finland & 14 & 377 & 8 & 26,93 & 1 & 1 & 8 & 5523904 & 2,53 & 68,25 \\
\hline 26 & Greece & 9 & 194 & 7 & 21,56 & 0 & 1 & 5 & 10919459 & 0,82 & 17,77 \\
\hline 27 & Taiwan & 9 & 103 & 5 & 11,44 & 0 & 0 & 3 & 23395600 & 0,38 & 4,40 \\
\hline 28 & Portugal & 7 & 77 & 5 & 11 & 0 & 0 & 3 & 10304434 & 0,68 & 7,47 \\
\hline 29 & Brazil & 7 & 65 & 3 & 9,29 & 0 & 0 & 2 & 209567920 & 0,03 & 0,31 \\
\hline 30 & Mexico & 5 & 407 & 4 & 81,4 & 2 & 3 & 3 & 128632004 & 0,04 & 3,16 \\
\hline 31 & Slovenia & 4 & 104 & 3 & 26 & 0 & 1 & 3 & 2065000 & 1,94 & 50,36 \\
\hline 32 & Cyprus & 4 & 59 & 4 & 14,75 & 0 & 0 & 3 & 1170000 & 3,42 & 50,43 \\
\hline 33 & Thailand & 3 & 22 & 2 & 7,33 & 0 & 0 & 1 & 68860000 & 0,04 & 0,32 \\
\hline 34 & Nigeria & 3 & 7 & 2 & 2,33 & 0 & 0 & 0 & 186000000 & 0,02 & 0,04 \\
\hline 35 & Bangladesh & 2 & 236 & 2 & 118 & 1 & 1 & 1 & 162910864 & 0,01 & 1,45 \\
\hline 36 & Tanzania & 2 & 6 & 1 & 3 & 0 & 0 & 0 & 55570000 & 0,04 & 0,11 \\
\hline 37 & Hungary & 2 & 3 & 1 & 1,5 & 0 & 0 & 0 & 9818000 & 0,20 & 0,31 \\
\hline 38 & Russia & 2 & 1 & 1 & 0,5 & 0 & 0 & 0 & 143439832 & 0,01 & 0,01 \\
\hline 39 & Serbia & 2 & 0 & 0 & 0 & 0 & 0 & 0 & 7057000 & 0,28 & 0,00 \\
\hline 40 & Chile & 1 & 32 & 1 & 32 & 0 & 0 & 1 & 18131850 & 0,06 & 1,76 \\
\hline 41 & San Marino & 1 & 27 & 1 & 27 & 0 & 0 & 1 & 33203 & 30,12 & 813,18 \\
\hline 42 & Iceland & 1 & 2 & 1 & 2 & 0 & 0 & 0 & 334252 & 2,99 & 5,98 \\
\hline 43 & Lebanon & 1 & 2 & 1 & 2 & 0 & 0 & 0 & 6007000 & 0,17 & 0,33 \\
\hline 44 & Colombia & 1 & 1 & 1 & 1 & 0 & 0 & 0 & 48654392 & 0,02 & 0,02 \\
\hline 45 & Egypt & 1 & 1 & 1 & 1 & 0 & 0 & 0 & 95690000 & 0,01 & 0,01 \\
\hline 46 & Rhodesia & 1 & 1 & 1 & 1 & 0 & 0 & 0 & 6930000 & 0,14 & 0,14 \\
\hline 47 & Saudi Arabia & 1 & 1 & 1 & 1 & 0 & 0 & 0 & 32157974 & 0,03 & 0,03 \\
\hline 48 & Argentina & 1 & 0 & 0 & 0 & 0 & 0 & 0 & 43847277 & 0,02 & 0,00 \\
\hline 49 & Czech Republic & 1 & 0 & 0 & 0 & 0 & 0 & 0 & 10560000 & 0,09 & 0,00 \\
\hline 50 & Libya & 1 & 0 & 0 & 0 & 0 & 0 & 0 & 6293000 & 0,16 & 0,00 \\
\hline
\end{tabular}

Abbreviations are available in the previous tables except for: TP/POP = Total publications per million inhabitants; TC/POP = Total citations per million inhabitants; Population is in thousands.

Source: The authors 
Table 8 Publications classified by continents

\begin{tabular}{c|l|c|c|c|c|c|c|c}
\hline $\mathbf{R}$ & \multicolumn{1}{|c|}{ SUPRAREGIONS } & TP & TC & H & TC/TP & POPULATION & TP/POP & TC/POP \\
\hline 1 & Europe & 1,514 & 22,164 & 240 & 14.64 & $667,539,921$ & 2.27 & 33.20 \\
\hline 2 & North America & 861 & 16,978 & 80 & 19.72 & $360,405,165$ & 2.39 & 47.11 \\
\hline 3 & Asia & 228 & 3,749 & 72 & 16.44 & $3,203,612,963$ & 0.07 & 1.17 \\
\hline 4 & Oceania & 71 & 756 & 21 & 10.65 & $28,874,515$ & 2.46 & 26.18 \\
\hline 5 & Africa & 26 & 319 & 11 & 12.27 & $405,461,907$ & 0.06 & 0.79 \\
\hline 6 & Latin America & 15 & 529 & 7 & 35.27 & $18,131,850$ & 0.83 & 29.18 \\
\hline
\end{tabular}

Abbreviations are available in the previous tables.

Source: The authors

Table 9 Citing articles of LRP: Authors, universities, countries and journals

\begin{tabular}{|c|c|c|c|c|c|c|c|c|}
\hline $\mathbf{R}$ & Author & TP & University & TP & Country & TP & Journal & TP \\
\hline 1 & Volberda HW & 47 & U Manchester & 228 & USA & 4275 & Long Range Planning & 772 \\
\hline 2 & Buckley PJ & 34 & U Warwick & 218 & UK & 3720 & Industrial Marketing Manag & 266 \\
\hline 3 & Wright M & 32 & Erasmus U Rotterdam & 210 & Australia & 1150 & Tech Forecast Social Change & 254 \\
\hline 4 & Van Den Bosch F & 31 & U Cambridge & 194 & Spain & 1059 & J Business Research & 245 \\
\hline 5 & Das TK & 28 & Cranfield U & 186 & Germany & 1046 & J Business Ethics & 231 \\
\hline 6 & Lee $S$ & 28 & Copenhagen Bus Sch & 179 & Netherlands & 1003 & Strategic Management Journal & 228 \\
\hline 7 & Carmeli A & 27 & Aalto U & 178 & Canada & 950 & $\mathrm{~J}$ Cleaner Production & 216 \\
\hline 8 & Hitt MA & 24 & U North Carolina & 157 & PR China & 840 & Int J Technology Management & 200 \\
\hline 9 & Boiral 0 & 23 & U St Gallen & 152 & Italy & 786 & J Management Studies & 198 \\
\hline 10 & Jarzabkowski P & 22 & U Leeds & 146 & Taiwan & 688 & Management Decision & 192 \\
\hline 11 & King WR & 22 & U Nottingham & 143 & France & 634 & Int J Oper Prod Management & 190 \\
\hline 12 & Kodama M & 22 & National U Singapore & 142 & Finland & 629 & Technovation & 167 \\
\hline 13 & Liu $Y$ & 22 & Cardiff U & 132 & Sweden & 582 & Int J Production Economics & 166 \\
\hline 14 & Matthyssens P & 22 & U Strathclyde & 127 & Switzerland & 458 & R D Management & 144 \\
\hline 15 & Cunha MPE & 21 & Tilburg U & 125 & Denmark & 439 & Int J Project Management & 135 \\
\hline 16 & Elbanna S & 21 & Lappeenranta U Tech & 110 & South Korea & 351 & J Knowledge Management & 127 \\
\hline 17 & Gassmann 0 & 21 & Polytech U Milan & 110 & Belgium & 306 & Int Business Review & 123 \\
\hline 18 & Jabbour CJC & 21 & Delft U Techn & 108 & India & 301 & Service industries Journal & 122 \\
\hline 19 & Kumar V & 21 & U Oxford & 106 & Norway & 289 & J Product Innov Management & 118 \\
\hline 20 & Lederer AL & 20 & U Bath & 104 & Brazil & 277 & British J Management & 112 \\
\hline 21 & Lichtenthaler U & 20 & BI Norwegian Bus Sch & 103 & New Zealand & 265 & Int J Production Research & 110 \\
\hline 22 & $\mathrm{Lin} \mathrm{CH}$ & 20 & Loughborough U & 99 & Portugal & 244 & Indust Management Data Syst & 109 \\
\hline 23 & Sarstedt M & 20 & U Sheffield & 97 & Malaysia & 232 & J World Business & 108 \\
\hline 24 & Depablos PO & 19 & Vrije U Amsterdam & 97 & Singapore & 227 & $\mathrm{~J}$ Int Business Studies & 105 \\
\hline 25 & Teo TSH & 19 & ETH Zurich & 96 & Turkey & 226 & Expert Systems with Applic & 99 \\
\hline 26 & Lee $\mathrm{H}$ & 18 & Hong Kong Poly U & 96 & Austria & 218 & Techn Analysis Strat Manag & 99 \\
\hline 27 & Park Y & 18 & U Birmingham & 96 & Japan & 184 & European J Marketing & 98 \\
\hline 28 & Ringle CM & 18 & U Queensland & 96 & South Africa & 176 & Futures & 97 \\
\hline 29 & Ritala P & 18 & City U London & 95 & Iran & 165 & Organization Studies & 97 \\
\hline 30 & Westhead P & 18 & Lancaster U & 95 & Greece & 164 & Research Policy & 96 \\
\hline 31 & Duysters G & 17 & U NSW Sydney & 95 & Israel & 159 & J Management & 94 \\
\hline 32 & Henseler J & 17 & U Twente & 93 & Ireland & 156 & Omega Int J Manag Sci & 90 \\
\hline 33 & Kraus S & 17 & Arizona State U & 92 & Slovenia & 109 & Total Quality Manag Bus Excel & 90 \\
\hline 34 & Sadler-Smith E & 17 & U Groningen & 92 & Poland & 97 & Int J Management Reviews & 89 \\
\hline 35 & Von Krogh G & 17 & Aarhus U & 91 & Mexico & 86 & Sustainability & 88 \\
\hline 36 & Beamish PW & 16 & Aston U & 90 & UAE & 86 & Eur J Oper Res & 87 \\
\hline 37 & Bessant J & 16 & Bocconi U & 90 & Thailand & 73 & Knowledge Manag Res Pract & 86 \\
\hline 38 & Greenley GE & 16 & RMIT Melbourne & 89 & Russia & 64 & Organization Science & 85 \\
\hline 39 & Grover V & 16 & U Reading & 89 & Chile & 57 & IEEE Trans Eng Manag & 80 \\
\hline 40 & Heracleous L & 16 & U Montreal & 88 & Saudi Arabia & 53 & Int J Human Resource Manag & 80 \\
\hline
\end{tabular}

Abbreviations are available in the previous tables.

Source: The authors 


\subsection{Science mapping of LRP}

As mentioned above, science mapping or bibliometric mapping has become an important methodology in the field of bibliometrics (Cobo et al., 2015; van Eck and Waltman, 2010). This methodology attempts to show a spatial representation of the relationships between the different scientific actors in a field of knowledge that is dynamically changing (Small, 1997). In short, science mapping shows the structural and dynamic aspects of scientific research (Börner et al., 2003; Cobo et al., 2011b) and can be used as a complementary approach to bibliometric performance indicators (Cobo et al., 2012). Therefore, in order to obtain a more complete and complementary image of the results previously shown, this section presents science mapping of the main actors who publish in LRP. This analysis is performed using VOSviewer software, which visualizes bibliographic material through bibliographic coupling (Kessler, 1963) and analysis of citations and co-citations (Small, 1973). Bibliographic coupling analyzes documents cited (Cobo et al., 2011b) and occurs when two documents published in a journal cite the same third document. In the figure, the two documents are connected, but not the third, unless it also has a significant degree of bibliographic linkage by means of other documents. Therefore, for the purposes of this research, bibliographic coupling represents the highest productivity in LRP and shows how this research is connected to others (Merigó et al., 2016). Shared citations or co-citations study cited documents and occur when two documents receive a citation for a third document that has been published. The figure shows the two documents that have been cited by the article published in the journal, but not the latter. In this way, co-citation shows the research most cited in LRP and its connections (Merigó et al., 2017). Finally, the analysis of citations represents the sum of the citations that one scientific actor gives to another, and vice versa.

To carry out science mapping, the co-citation indicator of the most cited journals in LRP was analyzed first. Keep in mind that in this case, cocitation occurs when two documents published in different journals receive a citation from the same third document from another journal. Figure 2 presents the results with a threshold of 20 documents and the 100 strongest co-citation connections.
Note in Figure 2 that management journals such as the Strategic Management Journal, Academy of Management Journal and Academy of Management Review are very influential in LRP. This makes sense given the importance of these journals in the field of strategic management. Additionally, note that LRP dominates the central part of the graph, as it is very influential in its own articles. These results should not be surprising given that they are frequent in the analysis of co-citations of journals. One explanation for this is that authors often cite articles from the same source. It is also evident that LRP has a strong connection with journals in many areas but especially with Business and Management journals. Note that journals from other areas of business, such as marketing, are also frequently cited and clustered together. This denotes the interest of the different areas of business in the field of strategic management, and also highlights the breadth of topics published and cited in LRP.

To observe how citations evolve over time, Figures 3, 4 and 5 present a temporal analysis of co-citations of journals from the last three decades.

Note that in the last three decades, LRP appears quite influenced by itself. However, there is also a strong connection to and influence from several management journals mentioned above. All these journals are leaders in the field of strategic management and therefore logically influence LRP's publications. It is also interesting to note the appearance of many other journals in the last decade. One explanation is that in the 1980 s, there were not as many journals, and fewer articles were published than today, so the map of the decade 1988-1997 is less dense than that of the decade 2008-2017. The emergence of the Internet has also had a great impact on this phenomenon. Specifically, the digitalization of knowledge has made it easier for researchers to access different editorial platforms and articles in general.

To summarize these results, Table 10 presents a global report of the 30 most cited journals in LRP as well as a temporal analysis of the last three decades. 


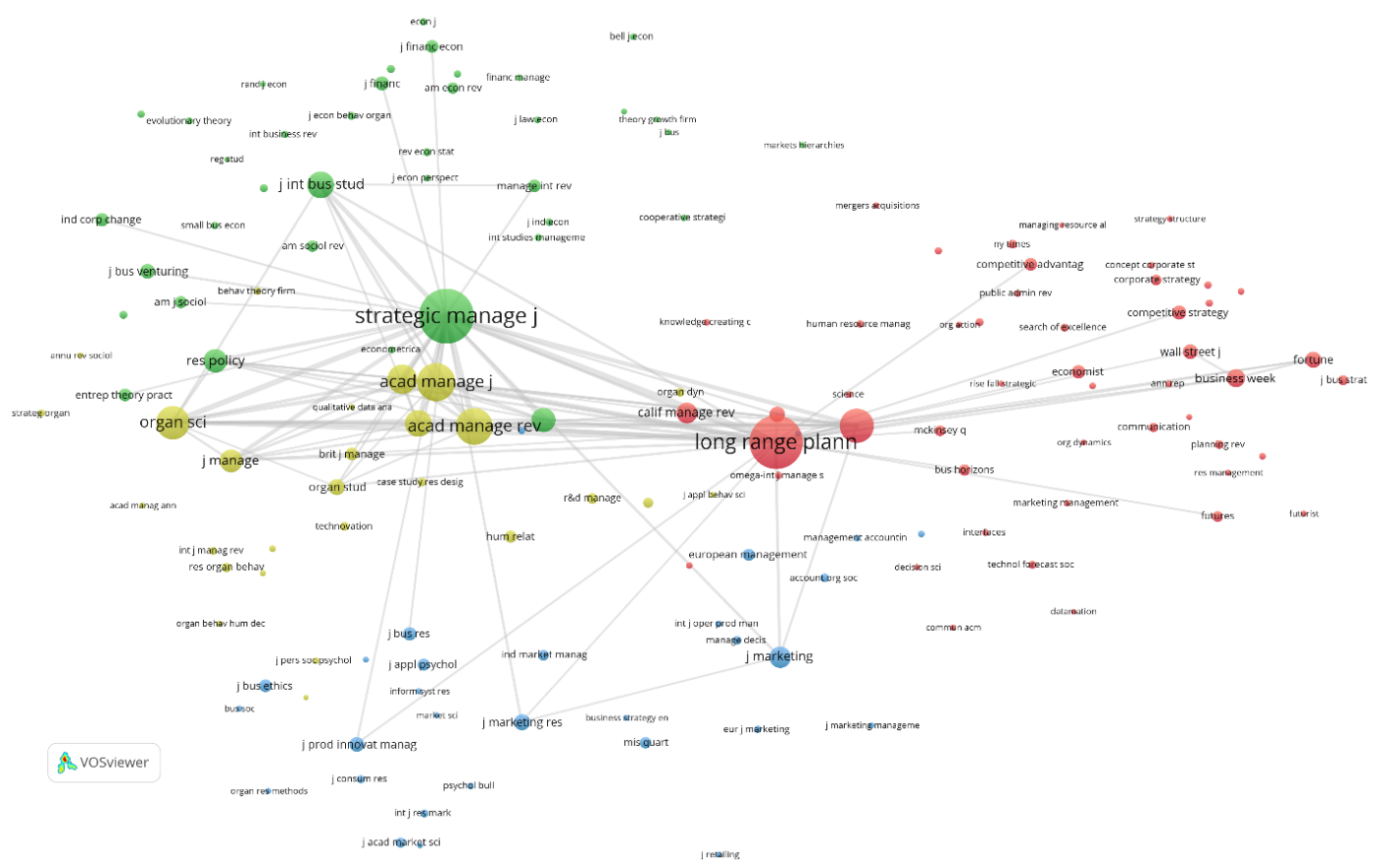

Figure 2 Co-citation of journals in LRP

Source: The authors

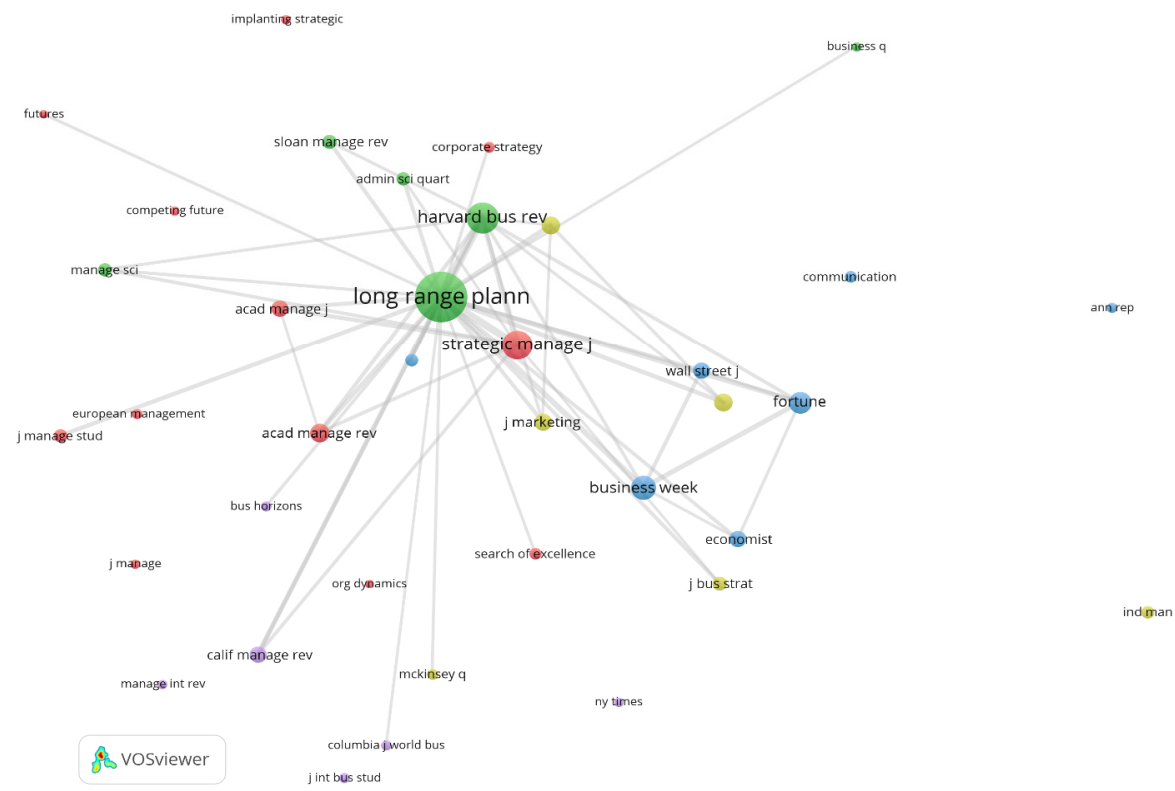

Figure 3 Co-citation of journals in LRP: 1988-1997

Source: The authors 


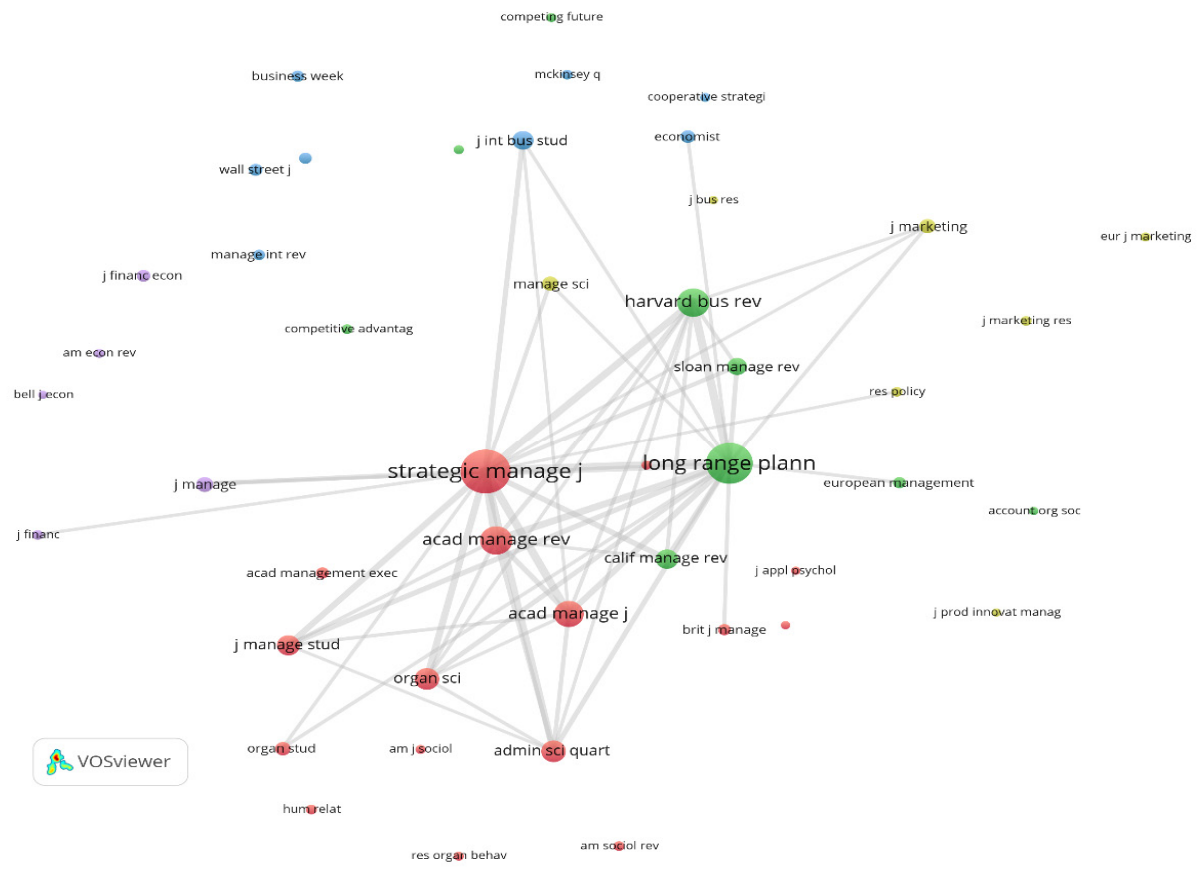

Figure 4 Co-citation of journals in LRP: 1998-2007 Source: The authors

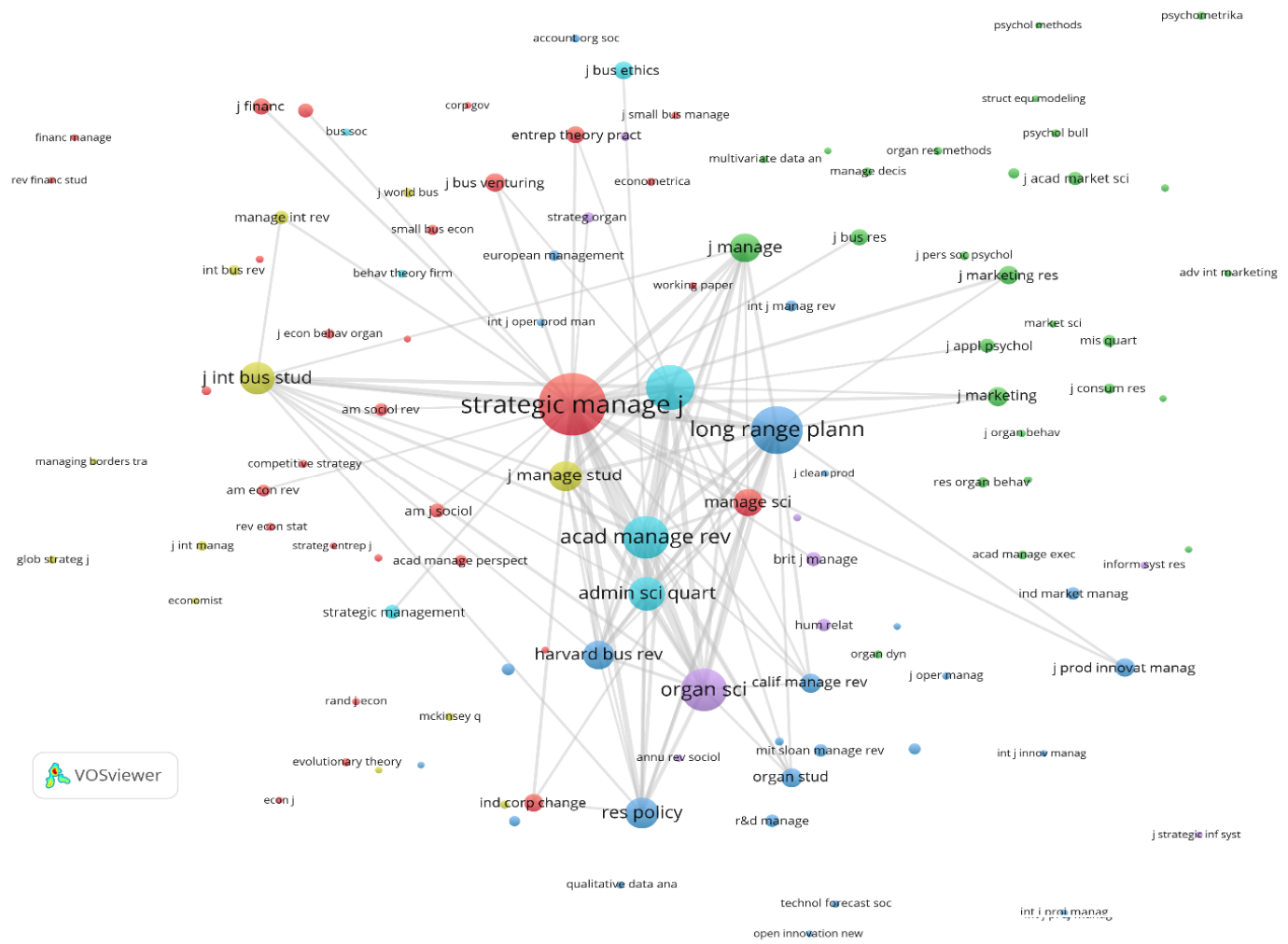

Figure 5 Co-citation of journals in LRP: 2008-2017

Source: The authors 


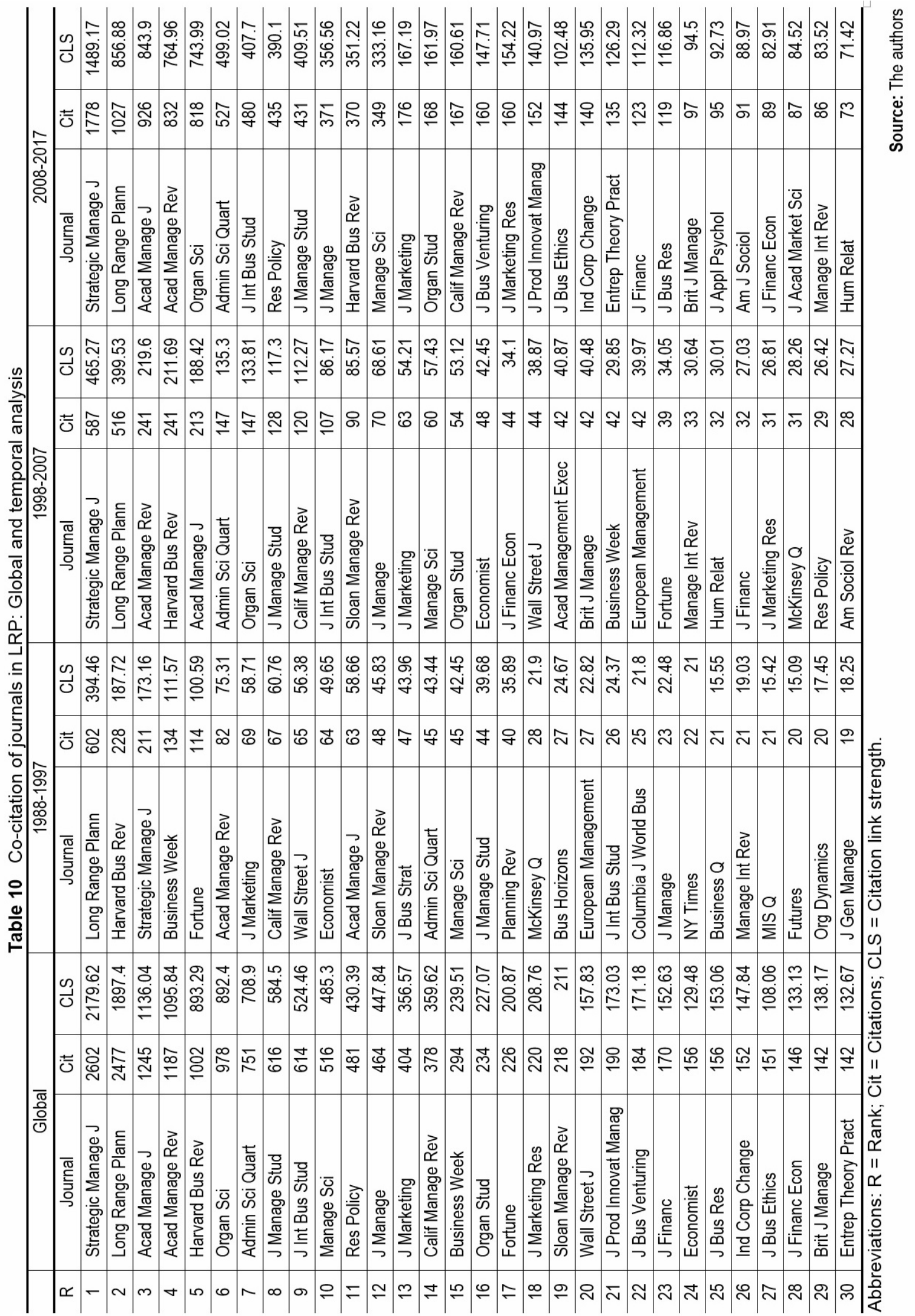


The results confirm what was stated in the previous figures and show a strong influence of management magazines on LRP. It is also important to highlight the influence of journals from different areas of business and management. A particularly striking case is the growing influence of the Journal of International Business Studies on LRP. Note that this is much easier to observe from the previous figures, where JIBS appears to be heavily influencing LRP in the last decade, 2008-2017.

Another interesting issue to analyze is the cocitation of authors. These are the authors most cited in LRP and the different connections they have with other researchers. Figure 6 presents the co-citation of authors with a threshold of 50 documents and the 100 strongest co-citation connections.

The figures clearly show that Porter is the center of the main nucleus and is therefore one of the most cited authors among LRP publications. It is also evident that other authors have received quite a few citations and are therefore at the center of some of the figure's subcores. Such is the case of Mintzberg, Eisenhardt, Hamel, and Teece, among others. Note that several of these authors appear in the list of documents most cited by LRP publications, and therefore, the results obtained in the performance analysis and science mapping are consistent.

Another key aspect to analyze is the bibliographic coupling of the universities that publish in LRP. Remember that bibliographic coupling occurs when two documents from different universities cite the same third document from another university. Note that the two connected universities appear on the map, but not the third cited university, unless you also have a significant degree of bibliographic linkage through other documents (Merigó et al., 2017). In short, the map depicted in Figure 7 presents the most bibliographically coupled universities that publish in LRP.

The major universities are consistent with Table 5. However, universities in the same country are often grouped together and have strong connections. For example, in Figure 7, English universities such as Cambridge University, London Business School, and
University of Birmingham, among others, tend to be grouped together.

Related to the above, the bibliographic coupling of the countries that publish frequently in LRP was analyzed. Bear in mind that this analysis was carried out with the country of origin of the universities that publish in the journals and not with the nationality of the authors, which can be very diverse. Figure 8 shows the results with a threshold of five documents and the fifty most representative bibliographical connections.

Note that the United Kingdom and the USA are the main nucleus of Figure 8. It is common in these types of figures to observe countries on the same continent close to each other. Such is the case of the European countries that are grouped in the left sector of the Figure. In the case of the USA and the United Kingdom, one factor that could explain their centrality and proximity is their linguistic closeness.

Finally, we analyze the most commonly used keywords by authors who publish in LRP. Note that the focus of the co-occurrence of keywords is on the list of keywords provided by the author. The graphical visualization of these words is a network graph. The size of the circles, which represent a keyword, are larger according to the relevance of this word in LRP. The network connections of these words are used to identify the most closely linked keywords. Figure 9 presents the results considering a threshold of 2 occurrences and the 100 most frequent cooccurrences.

At first glance, it is possible to observe that the subject matter of the articles published during these 50 years of LRP has been varied. However, some concepts stand out notably in the figure, such as business performance, innovation, strategy, competitive advantage and management. Obviously there are other keywords that represent the breadth of topics that have been published in LRP and still have much potential in the journal. It is therefore expected that LRP will continue to promote research on these topics in order to further explain the different business phenomena related to strategic planning. 


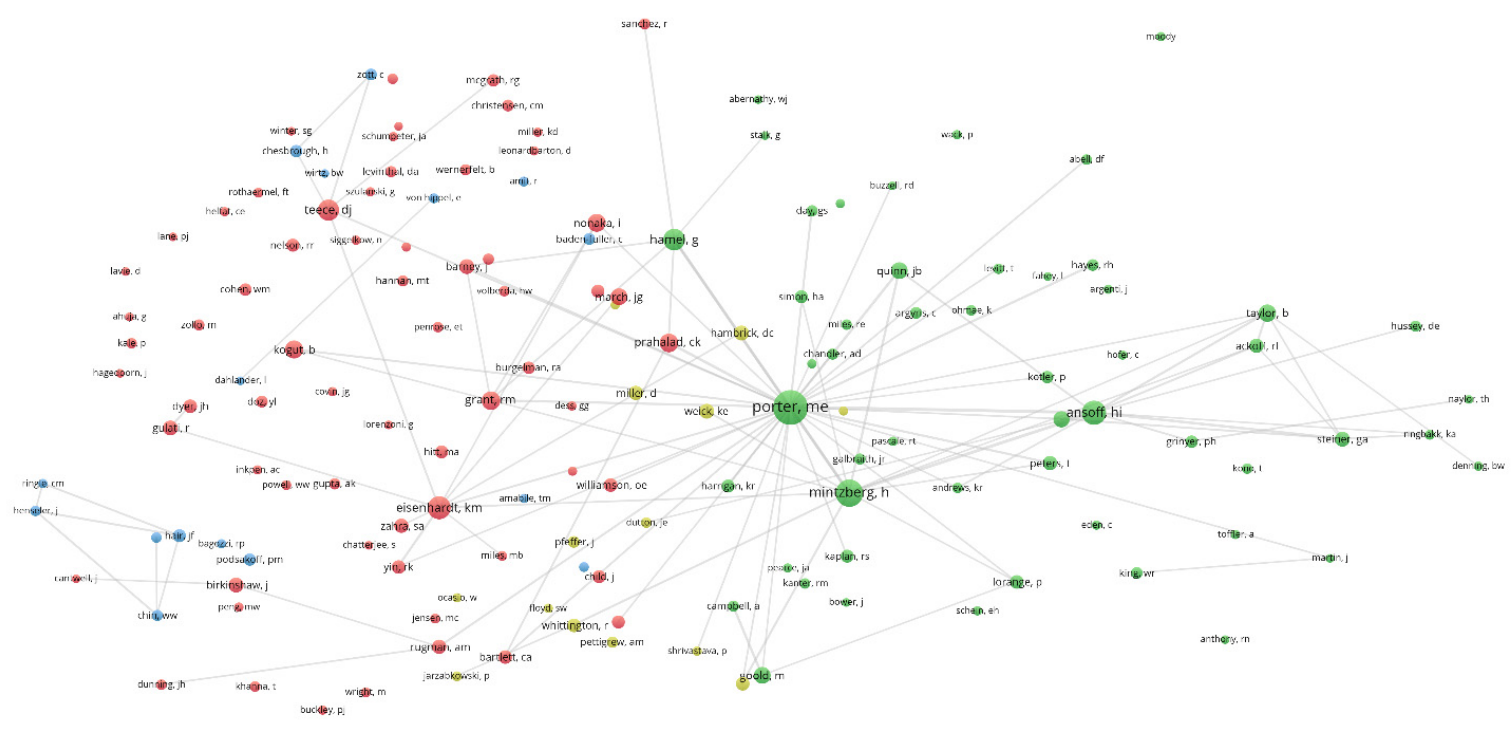

A vosviewer

Figure 6 Co-citation of authors cited in LRP Source: The authors

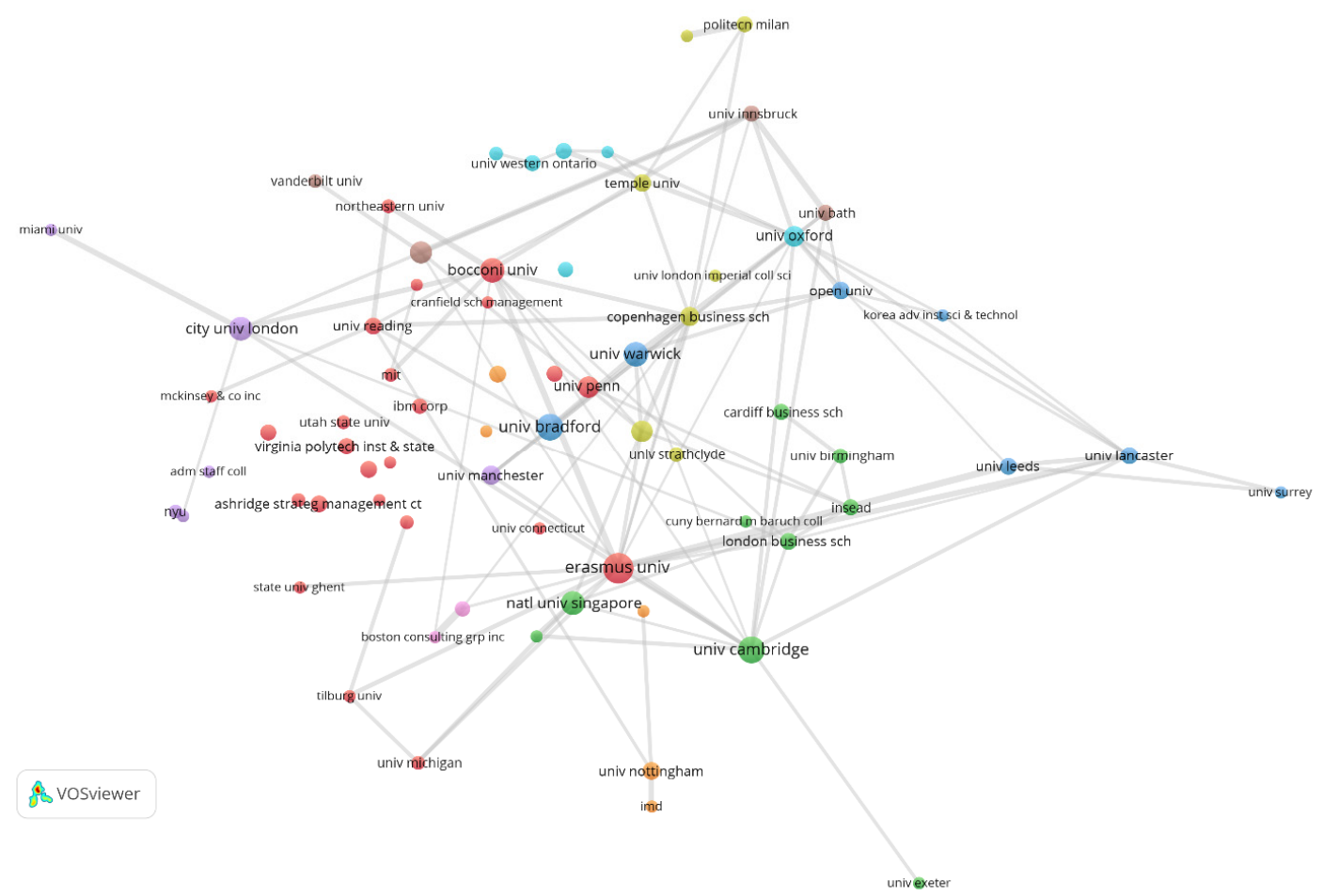

Figure 7 Bibliographic coupling of institutions publishing in LRP Source: The authors 


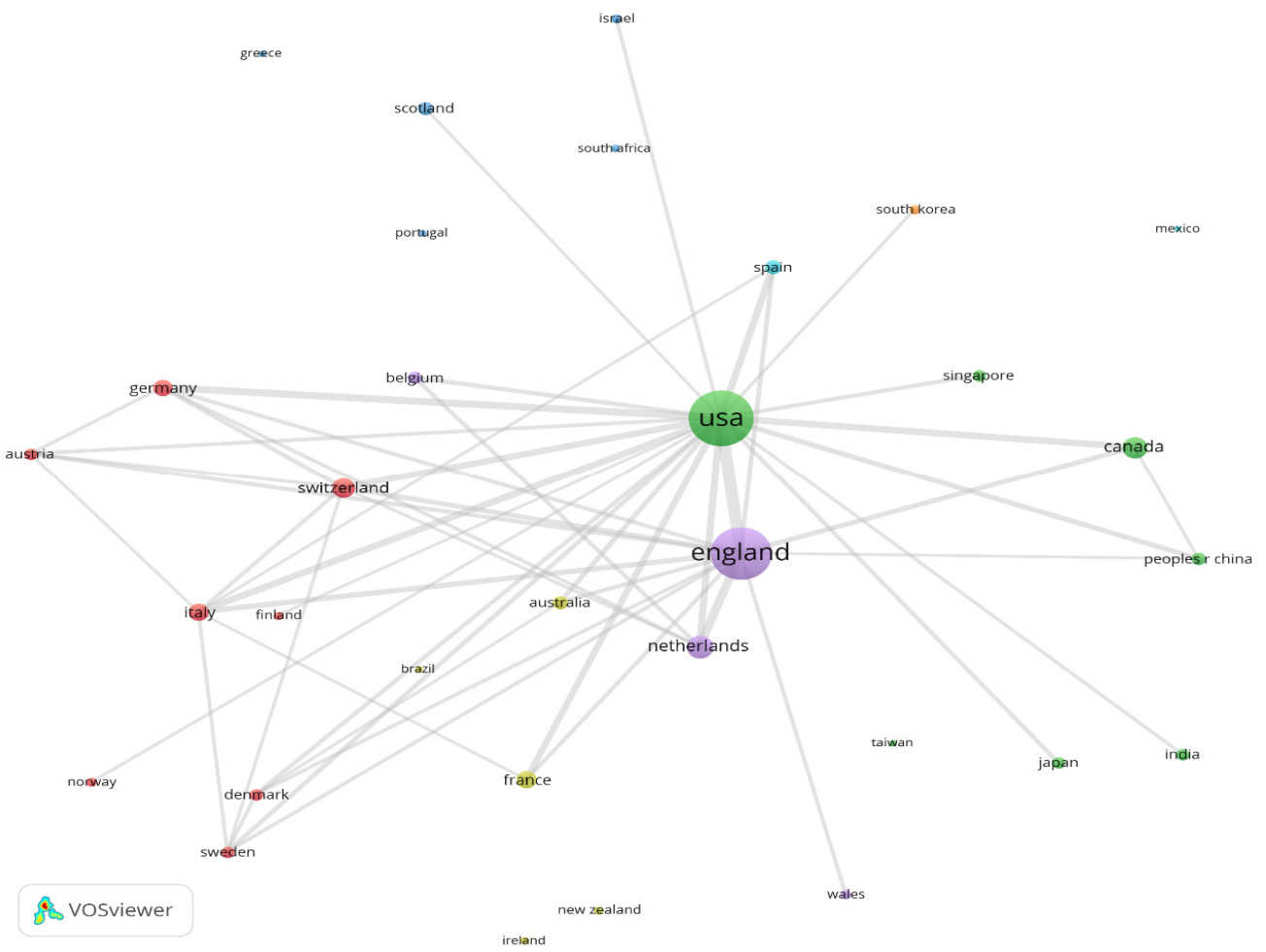

Figure 8 Bibliographic coupling of countries publishing in LRP

Source: The authors

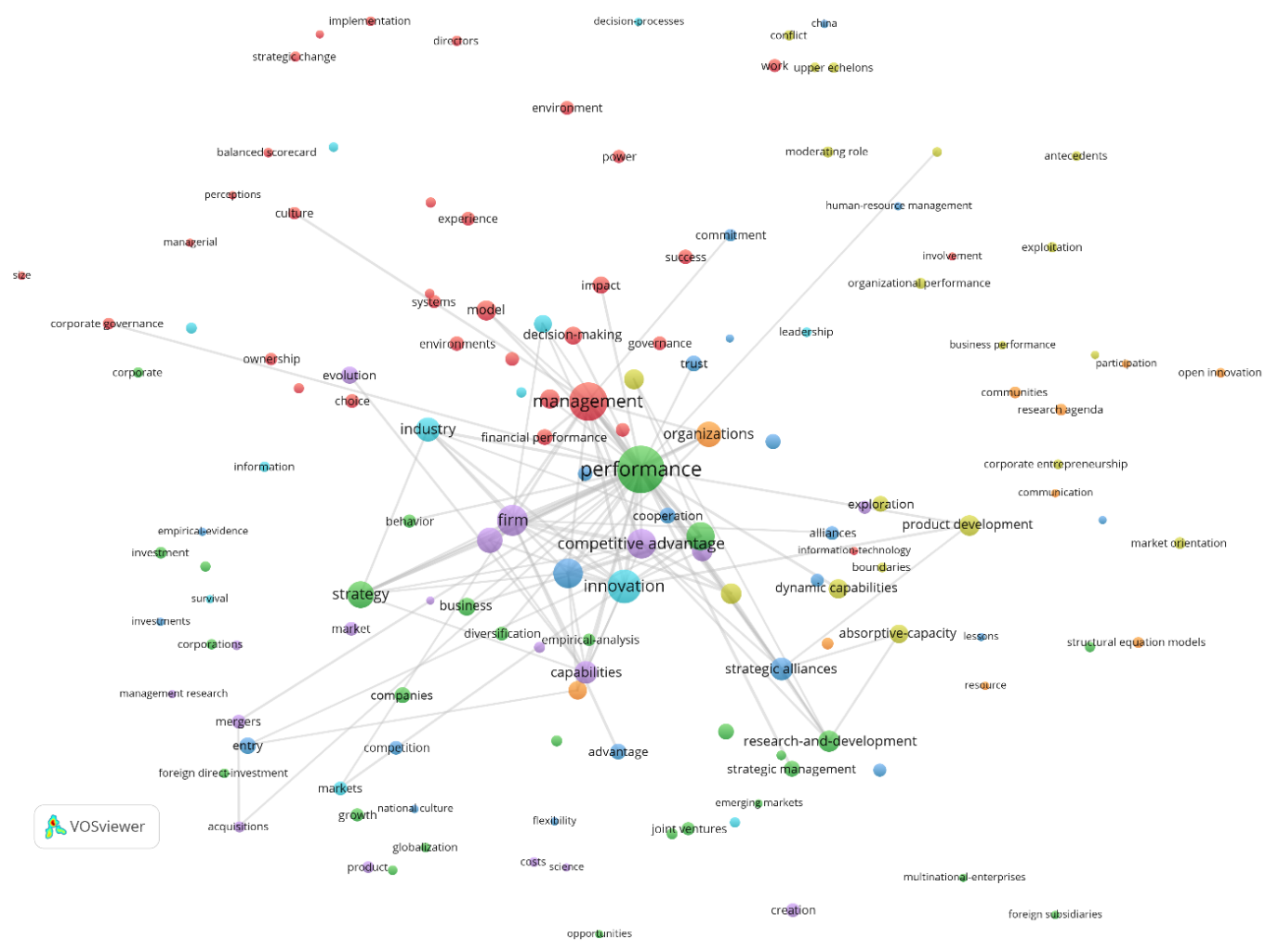

Figure 9 Co-occurrence of keywords (Keyword Plus) in LRP Source: The authors 


\section{Conclusion}

In recent decades, strategic planning has attracted considerable interest among researchers around the world and today continues to challenge them to understand both economic and corporate planning as well as large-scale projects (Laamanen, 2017). In this context, LRP is an important source of knowledge for researchers around the world who wish to understand strategic planning. In its 50 years and as the first strategy journal (Laamanen, 2017), LRP has played an important role in contributing relevant knowledge related to strategic planning. To celebrate this important anniversary, this paper seeks to provide a complete bibliometric analysis to identify the most significant results that occurred in the journal during its five decades. For this, the bibliometrics presented involve performance analysis and science mapping from all the research published in LRP between September 1968 and August 2018. The data were obtained from the Core Collection of the Web of Science database. The results confirm that LRP is one of the leading journals in the field of strategic planning and management.

The results of the performance analysis show that LRP has published documents from more than 50 countries around the world, with the UK leading in productivity of LRP publications. This makes sense because it is home to the journal's most productive and influential authors and universities. Another fact that explains this trend is that LRP originated in the UK. The USA is the journal's most influential country with the most citations, although in terms of productivity, it lags far behind the UK. It is important to mention that although LRP publications are concentrated in the UK and the USA, many other countries have published in the journal, confirming the global reach of the journal to which Laamanen's study (2017) refers.

As an important part of bibliometric analysis and to complement the results of the performance analysis, this paper developed a science mapping of all LRP publications. For this purpose, VOSviewer software was used. The results were consistent with those obtained in the performance analysis. However, one of the advantages of science mapping is to observe the connections between the variables in the journal's publications. Along these lines, it is evident that LRP publishes documents with a wide range of topics that are used to explain management and strategic planning. It is also possible to observe that the journal is strongly connected to Management journals such as Strategic Management Journal, Academy of Management Review, Journal of Management Studies, Organization Science, and Managerial Science, among others. From the science mapping, it is also evident that universities in the same country, as well as nearby countries, are strongly connected in LRP publications.

This article provides the main bibliometric results occurring in the 50 years of LRP. However, it is important to take into account some limitations. First, the dynamics of science imply that results can change with time, and therefore, condition the different variables analyzed in this study. Second, the data were obtained from the Core Collection of the Web of Science database, so the limitations of this database were transferred to this study. One of them is, for example, the complete counting system, in which documents signed by multiple authors or affiliations tend to have more importance in the analysis compared to those documents that appear with only one author. The science mapping done with VOSviewer was used to neutralize this limitation, since it uses a fractional counting system. The similarity and consistency between the results obtained from the performance analysis and the science mapping allow us to conclude that there is no significant deviation between the two counting methods. Third, the breadth of themes and disciplines in LRP has been highlighted. Therefore, some themes may receive more attention than others regardless of their relevance. Although researchers must take these limitations into account, this document identifies the most significant results in the 50 years of LRP's life, and its usefulness lies in the information presented in a comprehensive manner and considering different perspectives so that each reader understands the data according to his or her interests and priorities.sM

\section{References}

Alonso, S., Cabrerizo, F. J., Herrera-Viedma, \& E., Herrera, F., (2009). h-Index: A review focused in its variants, computation and standardization for different scientific fields. Journal of Informetrics 3, 273-289. https://doi.org/10.1016/j.joi.2009.04.001

Baier-Fuentes, H., Merigó, J.M., Amorós, J. E., GaviriaMarín, M., (2019). International entrepreneurship: a bibliometric overview. International Entrepreneurship and Management Journal 15, 385-429. https://doi.org/10.1007/s11365-017-0487-y 
Börner, K., Chen, C., \& Boyack, K. W. (2003). Visualizing knowledge domains. Annual Review of Information Science and Technology 37, 179-255. https://doi.org/10.1002/aris.1440370106

Callon, M., Courtial, J. P., Turner, W. A., \& Bauin, S. (1983). From translations to problematic networks: An introduction to co-word analysis. Social Science Information 22, 191-235. https://doi.org/10.1177/053901883022002003

Chen, C., (2006). CiteSpace II: Detecting and visualizing emerging trends and transient patterns in scientific literature. Journal of the American Society for Information Science and Technology 57, 359-377. https://doi.org/10.1002/asi.20317

Cobo, M. J., López-Herrera, A. G., Herrera-Viedma, E., \& Herrera, F. (2012). SciMAT: A new science mapping analysis software tool. Journal of the American Society for Information Science and Technology 63, 1609_ 1630. https://doi.org/10.1002/asi.22688

Cobo, M. J., López-Herrera, A. G., Herrera-Viedma, E., \& Herrera, F. (2011a). An approach for detecting, quantifying, and visualizing the evolution of a research field: A practical application to the Fuzzy Sets Theory field. Journal of Informetrics 5, 146-166. https://doi.org/10.1016/j.joi.2010.10.002

Cobo, M. J., López-Herrera, A. G., Herrera-Viedma, E., \& Herrera, F. (2011b). Science mapping software tools: Review, analysis, and cooperative study among tools. Journal of the American Society for Information Science and Technology 62, 1382-1402. https://doi.org/10.1002/asi.21525

Cobo, M. J., Martínez, M.A., Gutiérrez-Salcedo, M., Fujita, H., \& Herrera-Viedma, E. (2015). 25 years at Knowledge-Based Systems: A bibliometric analysis. Knowledge-Based Systems 80, 3-13. https://doi.org/10.1016/j.knosys.2014.12.035

Egghe, L. (2006). Theory and practise of the g-index. Scientometrics 69, 131-152. https://doi.org/10.1007/s11192-006-0144-7

Gaviria-Marin, M., Merigó, J. M., \& Baier-Fuentes, H. (2019). Knowledge management: A global examination based on bibliometric analysis. Technological Forecasting \& Social Change 140, 194-220. https://doi.org/10.1016/j.techfore.2018.07.006

Gaviria-Marin, M., Merigo, J. M., \& Popa, S. (2018). Twenty years of the Journal of Knowledge Management: a bibliometric analysis. Journal of Knowledge Management 22, 1655-1687. https://doi.org/10.1108/JKM-10-2017-0497

Glänzel, W. (2001). National characteristics in international scientific co-authorship relations. Scientometrics 51 , 69-115. https://doi.org/10.1023/A:1010512628145

Hirsch, J. E. (2005). An index to quantify an individual's scientific research output. Proceedings of the National Academy of Sciences of the United States of America 102, 16569-16572. https://doi.org/10.1073/pnas.0507655102

Kessler, M. M. (1963). Bibliographic coupling between scientific papers. American Documentation 14, 10-25. https://doi.org/10.1002/asi.5090140103

Laamanen, T. (2017). Reflecting on the past 50 years of Long Range Planning and a research agenda for the next 50. Long Range Planning 50, 1-7. https://doi.org/10.1016/j.Irp.2017.02.001
Martínez-López, F. J., Merigó, J. M., ValenzuelaFernández, L., \& Nicolás, C. (2018). Fifty years of the European Journal of Marketing: a bibliometric analysis European Journal of Marketing 52, 439-468. https://doi.org/10.1108/EJM-11-2017-0853

Merigó, J. M., Blanco-Mesa, F., Gil-Lafuente, A. M., \& Yager, R. R. (2017). Thirty years of the International Journal of Intelligent Systems: A bibliometric review. International Journal of Intelligent Systems 32, 526554.

https://doi.org/10.1002/int.21859

Merigó, J. M., Cancino, C.A., Coronado, F., \& Urbano, D. (2016). Academic research in innovation: a country analysis. Scientometrics 108, 559-593. https://doi.org/10.1007/s11192-016-1984-4

Merigó, J. M., Cobo, M. J., Laengle, S., Rivas, D., \& Herrera-Viedma, E. (2018). Twenty years of Soft Computing: a bibliometric overview. Soft Computing 23, 1477-1497. https://doi.org/10.1007/s00500-018-3168-z

Merigó, J. M, Pedrycz, W., Weber, R., \& de la Sotta, C. (2018). Fifty years of Information Sciences: A bibliometric overview. Information Sciences 432, 245268. https://doi.org/10.1016/j.ins.2017.11.054

Noyons, E. C. M., Moed, H. F., \& Luwel, M. (1999). Combining mapping and citation analysis for evaluative bibliometric purposes: A bibliometric study. Journal of the American Society for Information Science 50, 115131.

https://doi.org/10.1002/(SICl)10974571(1999)50:2<115::AID-ASI3>3.0.CO;2-J

Persson, O., Danell, R., \& Wiborg Schneider, J. (2009). How to use Bibexcel for various types of bibliometric analysis, in: Åström, F., Danell, R., Larsen, B. Schneider, J. (Eds.), Celebrating Scholarly Communication Studies: A Festschrift for Olle Persson at His 60th Birthday. International Society for Scientometrics and Infometrics, Leuven, pp. 9-24.

Peters, H. P. F., \& van Raan, A. F. (1991). Structuring scientific activities by co-author analysis: An exercise on a university faculty level. Scientometrics 20, 235255. https://doi.org/10.1007/BF02018157

Podsakoff, P. M., MacKenzie, S. B., Podsakoff, N. P., \& Bachrach, D. G. (2008). Scholarly influence in the field of management: A bibliometric analysis of the determinants of university and author impact in the management literature in the past quarter century. Journal of Management 34, 641-720. https://doi.org/10.1177/0149206308319533

Porter, A. L., \& Cunningham, S. W. (2005). Tech mining: exploiting new technologies for competitive advantage. John Wiley \& Sons Inc., Hoboken, NJ. https://doi.org/10.1002/0471698466

Small, H. (1973). Co-citation in the scientific literature: A new measure of the relationship between two documents. Journal of the American Society for Information Science 24, 265-269. https://doi.org/10.1002/asi.4630240406

Small, H. (1997). Update on science mapping: Creating large document spaces. Scientometrics 38, 275-293. https://doi.org/10.1007/BF02457414 
Small, H. (1999). Visualizing science by citation mapping. Journal of the American Society for Information Science 50, 799-813.

https://doi.org/10.1002/(SICl)10974571(1999)50:9<799::AID-ASI9>3.0.CO;2-G

Stiles, P. (2000). Bernard Taylor: A retirement tribute. Long Range Planning 33, 130-139.

https://doi.org/10.1016/S0024-6301(99)99105-7
Van Eck, N. J., \& Waltman, L. (2010). Software survey: VOSviewer, a computer program for bibliometric mapping. Scientometrics 84, 523-538.

https://doi.org/10.1007/s11192-009-0146-3

Wise, J. A. (1999). The ecological approach to text visualization. Journal of the American Society for Information Science 50, 1224-1233.

https://doi.org/10.1002/(SICl)10974571(1999)50:13<1224::AID-ASI8>3.0.CO;2-4

\section{$\triangle$ Correspondence}

\section{José M. Merigó}

School of Systems, Management and Leadership Faculty of Engineering and Information Technology University of Technology Sydney

81 Broadway, Ultimo, 2007 NSW, Australia

E-mail: jose.merigo@uts.edu.au 